\title{
Physical protection in aggregates and organo- mineral associations contribute to carbon stabilization at the transition zone of seasonally saturated wetlands
}

\author{
Anna Kottkamp ( $\square$ akottkam@terpmail.umd.edu ) \\ University of Maryland at College Park https://orcid.org/0000-0001-6527-1942 \\ Charles Nathan Jones \\ The University of Alabama \\ Margaret A. Palmer \\ SESNYC: National Socio-Environmental Synthesis Center \\ Katherine L. Tully \\ University of Maryland at College Park
}

\section{Research Article}

Keywords: soil organic carbon (SOC), seasonally saturated wetlands, SOC stabilization, physical protection of SOC in aggregates, organo-mineral associations, SOC stocks

Posted Date: March 30th, 2021

DOI: https://doi.org/10.21203/rs.3.rs-358092/v1

License: (c) (i) This work is licensed under a Creative Commons Attribution 4.0 International License.

Read Full License 


\section{Abstract}

Wetlands store significant soil organic carbon (SOC) globally, yet this SOC is sensitive to climate and land use change. Seasonally saturated wetlands experience fluctuating hydrologic conditions that may promote the physicochemical mechanisms known to control SOC stabilization in upland soils; these wetlands are therefore likely to be important for SOC storage at the landscape-scale. We investigated the role of physicochemical mechanisms of SOC stabilization in five seasonally saturated wetlands to test the hypothesis that these mechanisms are present, particularly at the transition zone between wetland and upland where saturation in the upper soil profile is most variable. At each wetland, we monitored water level and collected soil samples at five points along a transect from frequently saturated basin edge to rarely saturated upland. We quantified physical protection of SOC in aggregates and organomineral associations in mineral horizons to $0.5 \mathrm{~m}$ depth. As expected, SOC decreased from basin edge to upland. In the basin edge and transition zone, the majority of SOC was physically protected in macroaggregates. By contrast, overall organo-mineral associations were low, with the highest Fe concentrations ( $5 \mathrm{mg} \mathrm{Fe} \mathrm{g}^{-1}$ soil) in the transition zone. While both stabilization mechanisms were present in the transition zone, physical protection is more likely to be a dominant mechanism of SOC stabilization in seasonally saturated wetlands. As future climate scenarios predict changes in wetland wet and dry cycles, understanding the mechanisms by which SOC is stabilized in wetland soils is critical for predicting the vulnerability of SOC to future change.

\section{Introduction}

Wetlands are a major component of the terrestrial carbon (C) cycle and sequester disproportionately large C stocks for their area (Mitsch et al. 2013). Given their C sequestration potential, wetland soils are the focus of current conservation and restoration efforts to help offset rising $\mathrm{C}$ emissions (Griscom et al. 2017). Research to date has primarily focused on soil organic C (SOC) of permanently saturated wetlands, where anoxia and subsequently slow decomposition typically enact a strong environmental control on SOC storage. However, a considerable yet frequently overlooked subset of wetlands are seasonally saturated and therefore experience dry, oxic conditions annually (e.g., vernal pools, Delmarva Bays, Prairie Potholes; Zedler 2003, Brooks 2005, Calhoun et al. 2017). Under the existing understanding of wetland SOC storage, periodic drying of seasonally saturated wetlands might be expected to stimulate C emissions and SOC loss (Miao et al. 2017). Contrary to this expectation, seasonally saturated wetland soils can sequester large stocks of SOC (Pearse et al. 2018; Tangen and Bansal 2020), though little is known about the mechanisms that could promote long-term SOC storage in seasonally saturated wetlands. As wetting and drying cycles in wetlands are expected to become more extreme with changes in land use and climate (e.g., Fennessy et al. 2018; Lee et al. 2020), understanding the mechanisms of SOC storage in seasonally saturated wetlands is critical to predicting the vulnerability of SOC to future change.

Given the unique condition of annual drying in seasonally saturated wetlands, mechanisms that control SOC dynamics in drier upland (terrestrial) soils may also contribute to SOC stabilization in these systems. 
Clay content has historically been used as proxy for SOC stabilization with mineral surfaces in upland soils (Keiluweit et al. 2018; Oades 1988) and has been assumed to also play a major role in wetland SOC sequestration (Daugherty et al. 2019). However, clay content alone does not clarify mechanisms of SOC accumulation and stabilization, especially in seasonally saturated soils where $C$ cycles are influenced by numerous hydrologic and biogeochemical factors (e.g., LaCroix et al. 2019). Beyond clay content, two physicochemical mechanisms of SOC stabilization are known to control long-term storage of SOC in upland soils: (1) physical protection of SOC within aggregates and (2) organo-mineral associations (Kaiser and Guggenberger 2000; Six et al. 2000; Moni et al. 2010; Schmidt et al. 2011). Though physicochemical mechanisms of SOC stabilization are understudied and assumed to be negligible in wetlands, the fluctuating hydrologic and biogeochemical conditions of seasonally saturated wetlands warrant their further study in these dynamic ecosystems.

Physical protection of SOC in aggregates is a dominant control on SOC storage in upland soils. Aggregates are associations between soil particles such as clay, silt, and organic matter which may protect SOC for years to decades by limiting microbial access to $C$ and reducing decomposition (Lehmann and Kleber 2015; Puget et al. 2000). Aggregates may be physically separated into size classes associated with SOC of distinct ages and chemical composition: macroaggregates are a dynamic, younger fraction related to plant detritus, while microaggregates represent a more biologically processed, older fraction (Six et al. 2004; von Lützow et al. 2007, 2006). Research from terrestrial soils suggests that aggregate formation and stability are influenced by soil moisture and wet-dry cycles (Denef et al. 2001, 2002), organic inputs (Park et al. 2007), biological activity (Blankinship et al. 2016), and interactions with clay and mineral oxides (Wagner et al. 2007). Several studies indicate the potential for physical protection of SOC within aggregates in permanently saturated wetlands (e.g., Hossler and Bouchard 2010; Maietta et al. 2019), but the extent of aggregate-associated SOC in and around seasonally saturated wetlands is unknown.

Organo-mineral associations are a second type of physicochemical mechanism of SOC stabilization that has almost exclusively been studied in terrestrial soils (Kaiser and Guggenberger 2000). Strong interactions with iron ( $\mathrm{Fe}$ ) or aluminum (Al) can stabilize SOC for up to hundreds of years (Kleber et al. 2005; Kögel-Knabner et al. 2008; Mikutta et al. 2006; Torn et al. 1997; Wagai and Mayer 2007). Associations between SOC and Fe depend on the type and amount of soil Fe, ranging from adsorption or coprecipitation of SOC with Fe (hydr)oxides to chelation (Kaiser and Guggenberger 2000; Mikutta et al. 2014; Sodano et al. 2017). Wetland soils tend to be depleted in mineral oxides due to reduction and subsequent leaching losses under saturated conditions (Mitsch and Gosselink 2015). However, Fe (hydr)oxides may be retained in soils that are only intermittently saturated, such as the transition zone between seasonally saturated wetland and upland, thus promoting SOC stabilization via organo-mineral associations. Consequently, Fe and $\mathrm{Al}$ (hydr)oxides are better predictors of SOC levels than clay content in high moisture, acidic soils (Rasmussen et al. 2018). Thus, if Fe (hydr)oxides are present in seasonally saturated wetlands, these associations could contribute to the stability of wetland SOC during dry periods. 
Given the gaps in our understanding of how physicochemical mechanisms contribute to SOC storage in seasonally saturated wetlands, our objectives were to (1) quantify total SOC and hydrologic characteristics, (2) examine the role of physical protection of SOC in aggregates, and (3) determine the extent of organo-mineral associations from the frequently saturated edge of the wetland basin to the rarely saturated upland. We investigated associations between SOC, aggregates, and Fe across a gradient of mean water level using aggregate size fractionation and selective Fe extractions at five seasonally saturated wetlands. Across the wetland-upland gradient, we focus our study on the intermittently saturated transition zone, which dries annually with water table drawdown during the growing season. Transition zone soils contain intermediate SOC stocks compared to the basin and upland and are likely important sites for SOC storage on the landscape scale; however, the role of SOC stabilization mechanisms in transition zone soils has not been quantified (Webster et al. 2011; Fenstermacher 2012; LaCroix et al. 2019; Chanlabut et al. 2020). We hypothesized that both aggregate- and Fe-associated C would be greatest in the hydrologically dynamic transition zone. Given the annual drying of seasonally saturated wetland systems, we expect physicochemical mechanisms of SOC stabilization to be most relevant under dry soil conditions, which may become increasingly prevalent under future climate change.

\section{Methods}

\subsection{Study sites}

This study was located on the Delmarva Peninsula in eastern U.S.A., which is bordered by the Chesapeake Bay on the west and the Atlantic Ocean on the east. Mean monthly temperature ranges from $1.3^{\circ} \mathrm{C}$ (January) to $25.1^{\circ} \mathrm{C}$ (July). Mean annual precipitation is $1105 \mathrm{~mm}$ and is distributed evenly through the year (Supplementary Fig. 1). Study wetlands are on two properties of The Nature Conservancy which are $<5 \mathrm{~km}$ apart and contain numerous seasonally saturated freshwater wetlands. Water table fluctuations are primarily driven by seasonal evapotranspiration (Lee et al. 2020), with maximum surface water expression in late spring and wetland drawdown over the growing season from May to September (Brooks 2005).

We selected five seasonally saturated wetlands with similar mineral soils (Order: Ultisols, Suborders: Udults and Aquults), depressional shape (Fig. 1b), and vegetation. Given the acidity of the soils (Supplementary Fig. 2), calcium carbonates were assumed to be negligible. Surrounding forest is comprised of Acer rubrum, Quercus phellos, Liquidambar styraciflua, and Nyssa sylvatica overstory with Ilex opaca, Magnolia virginianica, Clethra alnifolia, and Vaccinium corymbosum understory.

\subsection{Field methods}

\subsubsection{Establishing sample points along transect at each wetland}


At each wetland, we established one 20-25 m transect with five evenly spaced sample points (4-5 m apart) extending from the frequently saturated "basin edge" (sample point A on the transect) to the rarely saturated "upland" (sample point E on the transect; Fig. 1a). The basin edge sample point was located at the minimum extent of ponded water observed during the 2017 water year, where A horizons were > 15 $\mathrm{cm}$ thick. The upland was designated as the elevated area with sandy soils around each wetland (Stolt and Rabenhorst 1987). Specifically, the upland sample point was located where (a) upland trees and understory vegetation were present and (b) no hydromorphic features were found in the upper $0.5 \mathrm{~m}$ of the soil (Supplementary Fig. 3).

\subsubsection{Characterizing hydrologic conditions at each sample point}

To characterize hydrologic conditions at sample points along the wetland transects, we used a combination of 1-year of continuous water level measurements, surveyed sample point elevations, and a simple interpolation procedure. Across all wetlands, we measured wetland and upland water levels at 15minute intervals throughout water year 2018 (Oct 1, 2017-Sept 31, 2018) using HOBO U20 water level loggers (HOBO, Onset Computer Corporation, Bourne, $\mathrm{MA}$ ). We measured wetland water levels in surface water stilling wells located near the center of each wetland, and we measured upland water level in wells located near the upland sample point (Fig. 1a). We also measured relative elevations of sample points along each transect using a TOPCON RL-H5A Laser Level (Topcon Positioning Systems, Livermore, CA). Finally, we estimated mean daily water level at each sample point by interpolating between the edge of surface water inundation and the upland water level in the well. Notably, this procedure accounts for the dynamic expansion and contraction of surface inundation along each transect. Further, while seasonally saturated wetlands may experience temporary groundwater mounding (Phillips and Shedlock 1993; Rosenberry and Winter 1997), this approach assumed linearity given the relatively small spatial scale and low-relief landscape. Interpolated water levels were comparable to observed water levels as measured biweekly from May to August $2018\left(R^{2}=0.87\right.$, Supplementary Fig. 4). For each transect point at each wetland, we calculated the mean water level for water year 2018 from daily water levels ( $n=365$ at each sample point). Higher, more positive values for mean water level indicate frequently saturated conditions at the basin edge, while lower, negative water levels indicate rarely saturated conditions at sample points towards the upland. A link to water level data, surveyed transect elevations, and interpolation procedure can be found in the Availability of Data and Material section.

We examined continuous hydrologic data (e.g., mean water level) instead of categorical transect points (e.g., A, B, etc.), as mean water level varied not only across the transect but also at a given transect point among wetlands. This allowed us to characterize the relationship between hydrologic conditions and physicochemical mechanisms of SOC stabilization (e.g., physical protection in aggregates and organomineral associations). In addition to mean water level, we quantified hydrologic variability as "saturation events" in the upper $0.5 \mathrm{~m}$ of soil by calculating the number of times that water level rose above a threshold (mean water level >-0.5 m) in water year 2018. To characterize reducing conditions, Fe oxide coated Indicator of Reduction In Soils (IRIS) films were deployed along each transect in April 2019 and 
analyzed after 30 days (Appendix A; Rabenhorst 2018; Castenson and Rabenhorst 2006). In the upper 0.5 $\mathrm{m}$ of the soil profile, all hydrologic metrics indicate frequently saturated conditions at sample points $A$ and $B$, rarely saturated conditions at sample points $D$ and $E$, and intermittently saturated conditions consistent with a transition zone near sample point C (Fig. 2; Supplementary Table 1).

\subsubsection{Soil sampling}

We used a gouge auger to collect soils to $1.0 \mathrm{~m}$ depth from sample points A-E along a transect at each of the five wetlands in June 2018. However, we focused our analysis on the first two mineral horizons from the upper $0.5 \mathrm{~m}$ of soil as this zone experiences the largest fluctuations in water level (Fig. 2a) and contains higher SOC concentrations than deep soils. We elected to sample by pedogenic horizon instead of arbitrary depth limits given the differences in soil type between transect points. In general, the first mineral horizon was approximately $5-20 \mathrm{~cm}$ in depth and the second mineral horizon was approximately 20-45 cm in depth. 0 horizons were excluded from analysis as they were high in fresh organic matter inputs and low in mineral matrices necessary for stabilization. Three replicate cores from each of the A-E points were separated by horizon; replicates were combined and gently homogenized to obtain a representative sample for each horizon (Supplementary Fig. 3; Supplementary Table 2). Subsamples of $200 \mathrm{~g}$ were removed for aggregate analysis.

Additional samples for bulk density were collected using a McCauley peat sampler at sample points A and $\mathrm{B}$ and using a 3-inch diameter sharpened aluminum core at sample points $\mathrm{C}-\mathrm{E}$. Bulk density samples were separated into three depth increments $(0-10 \mathrm{~cm}, 10-30 \mathrm{~cm}$, and $30-50 \mathrm{~cm})$ and corrected for compaction using a simple linear correction (Walter et al. 2016). Bulk density was calculated by dividing dry mass by core volume for each increment, subtracting roots and rocks (Poeplau et al. 2017).

\subsection{Soil chemical analysis}

Soil moisture levels can fluctuate daily in seasonally saturated wetlands, and, as it was not within the scope of the study to collect multiple soil samples through time, we decided to air dry all soils prior to analysis. Drying soils before aggregate analysis standardizes soils and allows soils to be stored while avoiding the effects of freezing on SOC. Standardization is necessary because aggregate stability in fieldmoist soils may be a function of antecedent water content (Gollany et al. 1991). However, we recognize that drying samples may promote the formation of stable macroaggregates (Beare and Bruce 1993) and novel $\mathrm{Fe}-\mathrm{C}$ complexes following $\mathrm{Fe}^{2+}$ oxidation (Kaiser et al. 2015). Therefore, by analyzing air-dried soils, we present the upper limit for both aggregate-associated $\mathrm{C}$ and $\mathrm{Fe}-\mathrm{C}$ associations across the transect, to characterize the maximum potential contribution of physical protection and organo-mineral association to SOC stabilization in wetlands that dry seasonally.

Air dried soils were passed through a $2 \mathrm{~mm}$ sieve (excluding large roots and rocks) for analysis of $\mathrm{pH}$, texture, $\mathrm{C}$, nitrogen $(\mathrm{N})$, and Fe. We measured pH using an Orion 9165BNWP Sure-Flow Combination pH 
probe on field moist soils with a 1:2 soil to solution $\left(0.01 \mathrm{M} \mathrm{CaCl}_{2}\right)$ ratio. Texture was determined by the hydrometer method (Gee and Bauder 1986). Bulk C ( $\left.\mathrm{C}_{\text {bulk }}\right)$ and $\mathrm{N}$ were measured using dry combustion (LECO CHN-2000 analyzer; LECO Corp, St. Joseph, MI) with helium as the carrier gas and with a detection limit of $0.02 \%$ for total $\mathrm{N}$ and $0.01 \%$ for total $\mathrm{C}$.

\subsubsection{Physical protection of SOC determined by aggregate size class separation}

We examined water-stable aggregates on mineral horizons in the upper $0.5 \mathrm{~m}$ using the wet sieving protocol established by Six et al. (2000) and modified for wetland soils by Maietta et al. (2019). Across the transect, some soils were drier while others were saturated at the time of collection. Dry soils were passed through a $4.75 \mathrm{~mm}$ sieve within $24 \mathrm{~h}$ of sampling and dried for 7 days. Saturated soils were dried for 3 days at room temperature, passed through a $4.75 \mathrm{~mm}$ sieve, then dried at room temperature.

Soils were wet-sieved within two months of collection into four size classes: (1) large macroaggregates ( $\geq 2000 \mu \mathrm{m})$, (2) small macroaggregates $(250-2000 \mu \mathrm{m})$, (3) microaggregates (53-250 $\mu \mathrm{m})$, and (4) silt/clay particles ( $<53 \mu \mathrm{m}$; includes only silt and clay sized particles not part of larger associations). Sieved samples were dried at room temperature with fans to evaporate excess water, then dried in a $65^{\circ} \mathrm{C}$ oven for 7 days before weighing. Aggregate samples were then gently crushed, and roots were separated on a $1 \mathrm{~mm}$ sieve. Remaining mass for each size class was weighed and analyzed for $\mathrm{C}$ and $\mathrm{N}$ using drycombustion (LECO CHN-2000 analyzer; LECO Corp, St. Joseph, MI). We measured sand content for size classes $>53 \mu \mathrm{m}$ on a $5 \mathrm{~g}$ subsample using the pipette method and subtracted sand mass to avoid overestimating aggregate mass (Appendix B; Elliott et al. 1991, Six et al. 2002).

\subsubsection{Organo-mineral associations between Fe-C determined by extractions}

We measured soil Fe concentrations using a dithionite-citrate-bicarbonate (DCB) extraction to estimate "total" extractable Fe oxides ( $\left.\mathrm{Fe}_{\mathrm{DCB}}\right)$ following the method by Darke and Walbridge (1994). A separate extraction with acid ammonium oxalate (AAO) was used to estimate "poorly crystalline" Fe species $\left(\mathrm{Fe}_{\mathrm{AAO}}\right.$; Coward et al. 2018; Darke and Walbridge 1994; Hall et al. 2018). For both extractions, the supernatant was filtered through a $0.45 \mu \mathrm{m}$ nylon filter (Tisch Scientific) and analyzed on an atomic absorption (AA) spectrometer on an air-acetylene flame (Perkin Elmer, Waltham, MA).

We also conducted inorganic Fe extractions on the mineral horizons to measure $\mathrm{C}$ associated with $\mathrm{Fe}$ (hydr)oxides (Darke and Walbridge 1994; Lopez-Sangil and Rovira 2013; Wagai et al. 2013) following the sodium dithionite- $\mathrm{HCl}$ (Dit-HCl) extraction described for use in wetland soils by Maietta et al. (2019). The Dit- $\mathrm{HCl}$ extraction removes Fe oxides ( $\left.\mathrm{Fe}_{\mathrm{Dit}-\mathrm{HCl}}\right)$ and is comparable to the DCB extraction of "total" $\mathrm{Fe}$ oxides but lacks an organic buffer, allowing us to measure concentrations of mineral-associated $\mathrm{C}$ in the extractant ( $\mathrm{C}_{\mathrm{Dit}-\mathrm{HCl}}$; Appendix $\left.\mathrm{C}\right)$. We also conducted a preliminary DCB extraction of Al (Darke and 
Walbridge 1994), finding low concentrations that were relatively unchanged across the transect and thus Al was not explored further (mean \pm standard error: $2.8 \pm 0.3 \mathrm{mg} \mathrm{Al} \mathrm{g}^{-1}$ soil). As such, we use "organomineral associations" to refer to the relationship between $\mathrm{C}$ and $\mathrm{Fe}$.

Extractions were conducted on a $0.5 \mathrm{~g}$ subsample of dried and ground soil. Extractants were filtered to $0.45 \mu \mathrm{m}$ using a nylon filter (Tisch Scientific, North Bend, $\mathrm{OH}$ ) and stored at $4{ }^{\circ} \mathrm{C}$ until analysis of organic C concentration with a TOC/TN Analyzer (Shimadzu Corporation, Kyoto, Japan; Sugimura and Suzuki 1988). Fe concentrations were measured with AA spectrometry as above.

\subsection{Calculations and statistical approach}

We calculated the proportion of total $\mathrm{C}$ in bulk soil $\left(\mathrm{C}_{\text {bulk }}\right)$ that was associated with each aggregate size class $\left(\mathrm{C}_{\text {aggregate }} / \mathrm{C}_{\text {bulki }}\right.$ Table 1, Eq. 1$)$. We also calculated the proportion of $\mathrm{C}_{\text {bulk }}$ that was associated with extracted Fe and used this normalized value for analyses $\left(\mathrm{C}_{\text {Dit-HCl}} / \mathrm{C}_{\text {bulki }}\right.$ Table 1 , Eq. 2$)$. We tested the main effect of mean water level, where a higher mean water level indicates more frequently saturated soils towards the basin edge and a lower, more negative water level indicates more rarely saturated soils towards the upland. We also tested the main effect of horizon by categorizing horizons in order of depth: first mineral horizon (1); second mineral horizon (2).

To test the effect of hydrology and horizon depth on SOC, physical protection in aggregates, and organomineral associations, we used linear mixed effects (LME) models with the Imer and ImerTest packages in R (Bates et al. 2015; Kuznetsova et al. 2017). In each test, mean water level (continuous) and horizon depth (categorical) were fixed effects, and we used backwards model selection to determine the best fixed effects structure (Zuur et al. 2009). A random effect (wetland) was included as part of the study design (Barr et al. 2013). Assumptions of normality and homogeneity of variance of model residuals were checked graphically. All model results are in the Supplementary Information (Supplementary Tables 316).

Initial analysis revealed different patterns of Fe concentrations between frequently saturated basin edge soils ("frequently saturated;" mean water level > - $0.5 \mathrm{~m}$ ) and upland soils ("rarely saturated;" mean water level $\leq-0.5 \mathrm{~m}$ ). Thus, for concentrations of Fe and associated C (e.g., $\mathrm{Fe}_{\mathrm{AAO}}, \mathrm{Fe}_{\mathrm{DCB}}, \mathrm{Fe}_{\mathrm{Dit}-\mathrm{HCl}}, \mathrm{C}_{\mathrm{Dit}-}$ $\mathrm{HCl} / \mathrm{C}_{\text {bulk }}$ ), we performed separate LME models on frequently saturated and rarely saturated soils to describe the effects of hydrology on organo-mineral associations.

We also used simple linear regression to test the relationship between SOC stocks and mean water level. Preliminary data exploration showed differences between $0-10 \mathrm{~cm}$ and $10-50 \mathrm{~cm}$ depth increments; therefore, we conducted separate analysis for SOC stocks from $0-10 \mathrm{~cm}$ and $10-50 \mathrm{~cm}$. Initially, this LME model included wetland as a random effect to account for differing wetland intercepts. However, the random term did not significantly improve the model (log-likelihood ratio test; Zuur et al. 2009; P > 0.05). Therefore, we removed the random term and conducted a simple linear regression. 
Statistical analysis was conducted using R statistical software v3.5.3 (R Development Core Team). Plots were created with the tidyverse and cowplot packages (Wickham 2017; Wilke 2019).

\section{Results}

\subsection{High hydrologic variability at sample points with a mean water level near $-0.5 \mathrm{~m}$}

Temperature in water year 2018 was within the 30 -year mean (mean monthly range: $-1{ }^{\circ} \mathrm{C}$ in January to $26^{\circ} \mathrm{C}$ in July 2018; Supplementary Fig. 1). Precipitation over the year was $1366 \mathrm{~mm}$, which is higher than average due to high precipitation in July and September 2018. Water levels varied $\sim 1 \mathrm{~m}$ over the year at each sample point, indicating dynamic hydrology typical for seasonally saturated wetlands of the region (Fig. 2a). Water levels rose from November to February and remained high until May. Water levels fell from June to September 2018 but rose in response to storm events in July and September.

Saturation within the upper $0.5 \mathrm{~m}$ of the soil profile was most variable at sample points with a mean water level of $-0.5 \mathrm{~m}$ (Fig. 2b) compared to rarely saturated sample points with lower (more negative) mean water levels (e.g., yellow and green lines, Fig. 2a) or compared to frequently saturated sample points with higher (more positive) mean water levels (e.g., dark blue lines, Fig. 2a). Accordingly, low Fe oxide reduction on IRIS films at sample point C (Supplementary Table 1) indicates heterogeneity of reducing conditions at the transition between basin edge and upland.

\subsection{SOC concentrations greatest at basin edge and declined toward rarely saturated upland}

Soil $\mathrm{C}_{\text {bulk }}$ concentration decreased as water levels declined from basin edge to upland (i.e., rarely saturated soils; $P=0.001$, Supplementary Table 3; Fig. 3a). With increasing horizon depth, $C_{\text {bulk }}$ concentrations decreased, as is typical for soils not affected by fluvial processes $(P<0.0001$, Supplementary Table 3). However, we observed contrasting relationships between SOC stocks and mean water level. In the top $0-10 \mathrm{~cm}, \mathrm{SOC}$ stocks increased as water levels declined toward rarely saturated soils ( $P=0.001$, Supplementary Table 4; Fig. 3b). Conversely, in the $10-50 \mathrm{~cm}$ depth increment, SOC stocks decreased with decreasing mean water level $(P<0.0001$, Supplementary Table 4; Fig. 3c).

Bulk soil clay (\%) decreased with decreasing mean water level $(P<0.0001$, Supplementary Table 5; Supplementary Fig. 2) while percent sand tended to increase. For soil pH, there was a significant interaction between horizon and mean water level. As mean water level decreased, soil pH decreased in the first mineral horizon but increased in the second mineral horizon $(P=0.0017$, Supplementary Table 6; Supplementary Fig. 2). 


\subsection{Physical protection of SOC in macroaggregates is greatest at the frequently saturated basin edge}

Among size classes, small and large macroaggregates contained the highest $\mathrm{C}_{\text {aggregate }}$ concentrations, while microaggregates and silt/clay contained lower $C_{\text {aggregate }}$ concentrations $(P<0.0001$, Supplementary Table 7). In the large macroaggregate size class only, $\mathrm{C}_{\text {aggregate }}$ significantly decreased as water levels declined toward rarely saturated soils $(P=0.00098$, Supplementary Table 8; Fig. 4a-d).

Normalized $\mathrm{C}_{\text {aggregate }} / \mathrm{C}_{\text {bulk }}$ proportions ( $\mathrm{mg} \mathrm{C} \mathrm{g}^{-1}$ bulk C; Table 1, Eq. 1) decreased with decreasing water level toward rarely saturated soils in the large macroaggregates but increased in all smaller size classes $(\mathrm{P}<0.05$ for all tests, Supplementary Table 9; Fig. $4 \mathrm{e}-\mathrm{h})$. Among size classes, normalized $\mathrm{C}_{\text {aggregate }} / \mathrm{C}_{\text {bulk }}$ proportions were highest in small macroaggregates and lowest in the smallest size classes $(P<0.0001$; Supplementary Table 7$)$. Normalized $C_{\text {aggregate }} / C_{\text {bulk }}$ proportions declined in the deeper horizon in large macroaggregates but increased in microaggregates $(P<0.05$, Supplementary Table 9; Fig. 4e).

\subsection{Fe-associated $\mathrm{C}$ highest in rarely saturated soils, declined sharply toward the basin edge}

We conducted separate statistical analysis for frequently saturated soils (mean water level >-0.5 m) and rarely saturated soils to understand the effect of mean water level on Fe species. In frequently saturated soils, Fe concentrations of all species were low (< $0.5 \mathrm{mg} \mathrm{Fe} \mathrm{g}^{-1}$ soil; Fig. 5a; Supplementary Fig. 5). In rarely saturated soils, $\mathrm{Fe}_{\mathrm{Dit}-\mathrm{HCl}}$ concentrations were highest where mean water level was approximately $0.5 \mathrm{~m}$ below the soil surface (transition zone), but concentrations declined toward the upland $(P<0.0001$, Supplementary Table 10; Fig. 5a). We observed similar patterns in poorly crystalline $\mathrm{Fe}_{\mathrm{AAO}}$ and total $\mathrm{Fe}_{\mathrm{DCB}}$ concentrations (Supplementary Table 11; Supplementary Table 12; Supplementary Fig. 5). However, the proportion of total $\mathrm{Fe}$ oxides that are poorly crystalline $\left(\mathrm{Fe}_{\mathrm{AAO}} / \mathrm{Fe}_{\mathrm{DCB}}\right)$ was highest at the basin edge and decreased linearly towards upland soils $(P<0.0001$, Supplementary Table 13; Supplementary Fig. 5).

Fe-associated C followed similar patterns to Fe and was also analyzed separately for frequently and rarely saturated soils (Fig. 5b). In frequently saturated soils, Fe-associated $\mathrm{C}_{\text {Dit-HCl }}$ concentrations showed no significant changes with decreasing water level. In rarely saturated soils, Fe-associated $\mathrm{C}_{\mathrm{Dit}-\mathrm{HCl}}$ concentrations decreased as mean water levels declined $(P=0.00035$, Supplementary Table 14).

To understand the relative amount of total $\mathrm{C}$ associated with Fe across the basin edge-upland gradient, we calculated the normalized $\mathrm{C}_{\text {Dit-HCl}} / \mathrm{C}_{\text {bulk }}$ proportion ( $\mathrm{mg} \mathrm{C} \mathrm{g}^{-1}$ bulk $\mathrm{C}$; Table 1, Eq. 2). When separated into frequently and rarely saturated soils, there was no significant association between mean water level and the proportion of $\mathrm{C}_{\text {Dit-HCl}} / \mathrm{C}_{\text {bulk }}(\mathrm{P}>0.05$, Supplementary Table 15; Fig. 5c). However, when we compared $\mathrm{C}_{\mathrm{Dit}-\mathrm{HCl}} / \mathrm{C}_{\text {bulk }}$ proportions across frequently versus rarely saturated soils as separate groups, a 
greater proportion of bulk soil $\mathrm{C}$ was associated with Fe in rarely saturated soils than frequently saturated soils (Welch's two sample t-test, $\mathrm{P}<0.05$ ).

\section{Discussion}

Seasonally saturated wetlands play an important role in SOC storage and stabilization (Pearse et al. 2018; Chanlabut et al. 2020), yet the mechanisms underpinning these processes are understudied. Here we show that $\mathrm{SOC}$ in and around seasonally saturated wetlands may be stabilized during dry periods by physical protection within macroaggregates and, to a lesser extent, by organo-mineral associations with Fe. Specifically, proportion of total $\mathrm{C}$ within large macroaggregates was highest at the frequently saturated wetland basin edge, suggesting that macroaggregates are likely to physically protect wetland SOC during seasonal drying. In contrast, Fe-associated $\mathrm{C}$ was low across the transect, peaking in the transition zone where saturation is most dynamic throughout the year. Overall, this research highlights the potential role of physicochemical mechanisms of SOC stabilization in wetlands that dry annually, indicating the need for research on how these mechanisms influence the resilience of SOC to future change.

\subsection{SOC changes across the gradient from basin edge-upland}

Our results demonstrate that mean water level can be used as a continuous indicator of hydrologic conditions to examine linear and nonlinear trends in soil characteristics across wetlands, building on prior studies that study SOC across discrete topographic categories (e.g., Chanlabut et al. 2020; LaCroix et al. 2019; Pearse et al. 2018; Webster et al. 2011; Webster et al. 2008). Low relief, wet forests are ubiquitous throughout the eastern U.S., but given their complexity they have typically been neglected in forest $\mathrm{C}$ models (e.g., Hurtt et al. 2019) and may be poorly represented by upland SOC models (Trettin et al. 2001). As remote sensing and geospatial methods improve wetland inundation detection (e.g., Lang and McCarty 2009; Lang et al. 2013; Evenson et al. 2018), relationships between SOC and hydrology could lead to more accurate models of SOC stocks in seasonally saturated wetlands.

Surprisingly, we found contrasting horizon-level trends in SOC stocks across the hydrologic gradient, wherein SOC stocks of surface soils $(0-10 \mathrm{~cm})$ were highest in the rarely saturated upland, while SOC stocks from 10-50 cm were greatest in frequently saturated soils of the basin edge (Fig. $3 \mathrm{~b}-\mathrm{c}$ ). As expected, wetland SOC stocks from 10-50 cm decreased from basin edge to upland. However, SOC stocks from 0-10 cm increased from basin edge to upland, which we anticipate is due to higher root growth in shallow organic horizons of upland soils than in the basin edge (LaCroix et al. 2019).

Overall, our results indicate that the relationship between hydrology and $\mathrm{SOC}$ is a continuum and not a binary (e.g., wetland vs. upland). We observed greater SOC stocks from 10-50 cm in transition zone soils than upland soils (Fig. 3). Our findings reinforce the SOC storage potential of intermittently flooded mineral soil wetlands found by Chanlabut et al. (2020) in which intermittently flooded soils contained higher SOC than permanently flooded soils. While the transition zone makes up a small portion of the 
area of an individual wetland, the transition zones of many seasonally saturated wetlands may contribute to important biogeochemical functions on the landscape scale (although see Tangen and Bansal 2020) and therefore must be included to improve wetland SOC models and expand targets of wetland conservation for SOC storage (e.g., Bridgam et al. 2006).

We observed strong relationships between mean water level and SOC characteristics, though soil texture also changed across the transect. Clay content has been used as a proxy for SOC stabilization (Oades 1988), as SOC may be protected from microbial decomposition by being bound to clay surfaces or sequestered in aggregates under anaerobic conditions (Weil and Brady 2017). However, bulk soil C was not correlated with percent clay along the transects studied here (Supplementary Fig. 6); instead, we found relationships between macroaggregate content and SOC (Fig. 4). Thus, our method of examining aggregate size classes can distinguish between the relative importance of SOC stabilization via free clay mineral surfaces (silt/clay fraction) and physical protection within aggregates (micro- and macroaggregate fractions). Our results suggest that percent clay alone as a proxy for $\mathrm{C}$ stabilization may not capture spatial variability of SOC in seasonally saturated wetlands. Rather, mean water level may be a better proxy for SOC in seasonally saturated wetlands due to its effects on $\mathrm{C}$ stabilization mechanisms in these systems.

\subsection{Large macroaggregates contain the most SOC in basin edge soils}

Large macroaggregates ( $>2 \mathrm{~mm}$ diameter) contained the most SOC across the transect and were related to hydrologic gradients, indicating that physical protection of SOC in large macroaggregates contributes to SOC stabilization in soils at the basin edge. Both $\mathrm{C}$ concentration $\left(\mathrm{C}_{\text {aggregate }}\right)$ and the proportion of total $\mathrm{C}\left(\mathrm{C}_{\text {aggregate }} / \mathrm{C}_{\text {bulk }}\right)$ in large macroaggregates were highest in basin edge soils and were intermediate in the transition zones (Fig. 4). Because soils were dried prior to analysis for standardization, these results represent an upper limit for macroaggregate-associated $C$ in sampled wetlands. While few studies have quantified macroaggregates in mineral wetland soils, Cui et al. (2019), Maietta et al. (2019), and Hossler and Bouchard (2010) found that large macroaggregates store significantly more SOC than other aggregate size classes in organic wetland soils. Additionally, Maietta et al. (2019) found that macroaggregate $\mathrm{C}$ was highest in the lowest elevation marsh sample point, consistent with the increase in large macroaggregates toward the frequently saturated basin edge found in the present study. We note, however, that several of the wettest soils studied here did not contain large macroaggregates; therefore, we expect that hydrology, in addition to other factors such as root activity and microbial biomass (e.g., Blankinship et al. 2016), contribute to aggregation in wetland soils.

Physical protection of wetland SOC within large macroaggregates may be promoted by the influx of organic-rich water and frequently saturated conditions at the basin edge. The influx of C-rich water provides organic constituents that may increase macroaggregate stability by increasing sorption between organic matter and minerals at aggregate surfaces and by strengthening intra-aggregate structures through the diffusion of DOC (Park et al. 2007). Therefore, we posit that relatively high dissolved organic 
C concentrations in the study wetlands (30 mg C L-1; Hosen et al. 2018) promote aggregate stability. Soil saturation also influences aggregate formation and stability. Research from agricultural soils indicates that aggregates tend to increase under moderately high soil moisture compared to dry conditions (Blankinship et al. 2016). Further, multiple cycles of saturation and drying also tend to increase aggregates (Denef et al. 2001, 2002), which may be due to stronger interactions between organic matter and clay particles (Wagner et al. 2007), changes in the microbial community over time, or increases in macroaggregate cohesion (Cosentino et al. 2006). It is unclear how this extensive body of research on aggregates in agricultural soils applies to forest and wetland soils, as the wet-dry cycles in these studies are typically around 14 days (consistent with irrigation and subsequent drying), and agricultural soils are typically much drier on average than forested wetland soils. The influence of hydrologic cycles on longer (annual) timescales, such as those of seasonally saturated wetlands, is a critical area for new research, as intact aggregates may mitigate the effects of wet-dry cycles and reduce $\mathrm{C}$ emissions (Navarro-García et al. 2012).

We found that the three smaller aggregate size classes were associated with the majority of SOC in rarely saturated, upland soils but were less variable overall across the hydrologic gradient than large macroaggregates. The proportion of bulk soil $\mathrm{C}$ associated with smaller aggregate size classes $\left(\mathrm{C}_{\text {aggregate }} / \mathrm{C}_{\text {bulk }}\right)$ increased from basin edge to upland, but $\mathrm{C}$ concentration in smaller size classes did not change across the gradient (Fig. 4). As expected, smaller aggregate size classes contained lower $\mathrm{C}$ concentrations and $\mathrm{C}: \mathrm{N}$ than macroaggregates, indicating that microaggregates and silt/clay fractions consist of older, microbially derived C (Supplementary Table 12; Jastrow 1996; Six et al. 2000). Notably, SOC of microaggregates in uplands likely contributes to long-term SOC stabilization through strong adsorption reactions on mineral surfaces (Arachchige et al. 2018; Totsche et al. 2018).

\subsection{Relatively low organo-mineral associations present in transition zone and uplands}

Overall, Fe concentrations in our study wetlands are on the low end (0-5 $\mathrm{mg} \mathrm{Fe} \mathrm{g}^{-1}$ soil) of the typical range for wetlands in the Northeast and mid-Atlantic (0-12 $\mathrm{mg} \mathrm{Fe} \mathrm{g}^{-1}$ soil; National Cooperative Soil Characterization Database; LaCroix et al. 2019); thus, our results suggest a relatively low potential for organo-mineral associations in transition zone and upland soils that is constrained by low Fe concentrations. As we dried soils prior to analysis, these values represent the maximum levels of Fe that we would expect to find in the sampled soils, regardless of saturation level. Unsurprisingly, we observed the lowest Fe concentrations in frequently saturated soils ( $<1 \mathrm{mg} \mathrm{Fe} \mathrm{g}^{-1}$ soil), where saturated conditions promote reduction and translocation of Fe (Chen et al. 2017; Fiedler and Sommer 2004). In contrast, modest accumulations of $\mathrm{Fe}$ (up to $5 \mathrm{mg} \mathrm{Fe} \mathrm{g}^{-1}$ soil) were observed in the transition zone. Approximately $50 \%$ of the Fe oxides in the transition zone were poorly crystalline $\left(\mathrm{Fe}_{\mathrm{AAO}} / \mathrm{Fe}_{\mathrm{DCB}}\right)$ and therefore more likely to have increased surface area available for transient complexation with C (Fig. 3; Supplementary Fig. 5; Hall et al. 2018; Coward et al. 2017). We expect that minor accumulations of Fe in transition zone soils 
are the result of periodic groundwater mounding that causes Fe to flow from uplands towards ponds (Phillips and Shedlock 1993) as well as seasonally dry conditions in upper transition zone soils that promote Fe (hydr)oxide retention. Additionally, research in permafrost soils suggests that vertical translocation may promote Fe accumulation at redox interfaces such as the upper soils of the transition zone (Herndon et al. 2017).

Constrained by low Fe levels, Fe-associated C concentrations were low overall (Fig S5) but were highest in the transition zone and decreased linearly toward the upland ( $\left.\mathrm{C}_{\text {Dit-HCl}} ; \mathrm{Fig} .5 \mathrm{~b}\right)$. Our results add to existing evidence that Fe may associate with SOC in places where Fe is present, such as redox interfaces like the transition zone (e.g., Riedel et al. 2013). While Fe-associated C concentrations were highest in the transition zone, the proportion of total SOC that was Fe-associated $\left(\mathrm{C}_{\text {Dit-HCl}} / \mathrm{C}_{\text {bulk }}\right)$ was highest in the upland, indicating that a greater fraction of $\mathrm{SOC}$ is in stabilizing organo-mineral associations in upland soils (up to $30 \%$; Fig. 5c). Of note, high proportions of poorly crystalline Fe and high ratios of C:Fe in all samples ( $>1$, Supplementary Table 16) indicate that most associations between $\mathrm{C}$ and Fe are transient and therefore susceptible to dissolution under seasonally saturated conditions (Kaiser and Guggenberger 2007; Wagai and Mayer 2007).

Organo-mineral associations in the frequently saturated basin soils were even lower ( $<1 \mathrm{mg} \mathrm{Fe} \mathrm{g}^{-1}$ soil) than in transition zone and upland soils, and only $10 \%$ of bulk soil $\mathrm{C}$ was associated with $\mathrm{Fe}_{\mathrm{Dit}-\mathrm{HCl}}$ at the basin edge (Fig. 5c). These results corroborate other work in mineral wetlands finding a lack of Fe (hydr)oxides in the wetland basin (LaCroix et al. 2019), suggesting that SOC in these frequently saturated soils are largely unprotected by organo-mineral associations. In fact, Fe may actually stimulate $\mathrm{C}$ loss under saturated conditions, as has been suggested in some drained and restored wetlands (Anthony and Silver 2020). As an alternative terminal electron acceptor, Fe facilitates anaerobic metabolism under reducing conditions. Further, the presence of reduced $\mathrm{Fe}^{2+}$ may both promote the oxidative activity of certain enzymes (Wang et al. 2017) and inhibit phenolic compounds which otherwise would constrain microbial decomposition (Wang et al. 2019). Thus, we expect the SOC-stabilizing influence of organomineral associations to promote SOC stabilization primarily during seasonally dry soil conditions, which may increase in frequency and magnitude in future.

While Fe concentrations in the present study are relatively low, the role of organo-mineral associations in SOC stabilization may be underestimated in wet soils with greater concentrations of Fe (e.g., Kramer and Chadwick 2018). For example, one study found Fe concentrations of up to $25-30 \mathrm{mg} \mathrm{Fe} \mathrm{g}^{-1}$ soil in vernal pools (Hobson and Dahlgren 1998), though Fe is rarely reported in studies of wetland SOC and thus the extent of wetlands with Fe concentrations of this magnitude are unknown. Further, while our results represents the upper limit of Fe oxides in sampled wetlands, future research including in-situ measurements (e.g., Anthony and Silver 2020) could characterize temporal dynamics of Fe-C associations in seasonally saturated wetlands. 


\subsection{The stability of SOC in wetlands that dry seasonally at the landscape scale}

We observed evidence of physicochemical stabilization of $C$ in seasonally saturated wetland soils. Of the two mechanisms studied here, a greater proportion of total SOC was physically protected within

macroaggregates $\left(\mathrm{C}_{\text {aggregate }} / \mathrm{C}_{\text {bulk }}\right)$ than was associated with Fe $\left(\mathrm{C}_{\text {Dit-HCl}} / \mathrm{C}_{\text {bulk }}\right)$, indicating that macroaggregates contribute more to SOC storage in wetlands that dry seasonally. Given how little is known about the stability of SOC in seasonally saturated wetlands, this study provides an initial assessment of physicochemical stabilization in a hydrologically dynamic wetland system and identifies an opportunity to further characterize physical protection of SOC in aggregates and organo-mineral associations under fluctuating saturation conditions.

Our research adds physicochemical mechanisms of SOC stabilization to the list of ecosystem processes (e.g. denitrification, gas fluxes) that may be enhanced in soils that experience dynamic saturation (Capps et al. 2014; Creed et al. 2013; Hefting et al. 2004; LaCroix et al. 2019; Ligi et al. 2014). More broadly, ecohydrological interfaces experience increased rates of biogeochemical processing and influence ecosystem response to environmental change (Krause et al. 2017). Coupled with the observation that small, depressional wetlands constitute a disproportionately high percentage of the total wetland perimeter length in many landscapes (Cohen et al. 2016), our results suggest that transition zones play an important role in landscape-scale SOC stabilization.

The future of stabilized SOC in wetlands is uncertain because the hydrologic regime of seasonally saturated wetlands is vulnerable to changes in land use and climate (Kolka et al. 2018). Under current hydrologic conditions, we expect SOC of seasonally saturated wetlands to be stabilized by physical protection in aggregates and, if there are abundant Fe or Al oxides, by organo-mineral associations particularly in the transition zone. However, as more extreme weather events are predicted with climate change (USGCRP 2017), increased incidence of severe precipitation, droughts, and warmer temperatures may lead to longer dry periods and more rapid transitions between wet and dry conditions. In transition zone and upland soils, we expect the effects of increased drying conditions to be moderated by associations between Fe and SOC in the short term. In the long term, increased storm events and subsequent leaching losses of Fe from upland soils may render SOC more susceptible to release as DOC (Kramer and Chadwick 2018) or loss via respiration. In basin soils, the low abundance of $\mathrm{Fe}-\mathrm{C}$ associations may lead to enhanced SOC loss with increased drying (e.g., Fissore et al. 2009), though macroaggregates may mitigate some of these effects. Overall, our work highlights the complex implications of future hydrologic change on SOC emissions and stabilization in wetlands (Bridgham et al. 2006; Kolka et al. 2018).

\section{Conclusions}

Hydrologic conditions influence physicochemical mechanisms of SOC stabilization, which our research suggests may play an important role in SOC storage in seasonally saturated wetlands. Overall, our results 
highlight distinct patterns in aggregate-associated $\mathrm{C}$ and, to a lesser extent, Fe-associated $\mathrm{C}$ from the basin edge to the hydrologically dynamic transition zone, suggesting that these mechanisms merit further study in soils that experience both saturated and dry conditions throughout the year. These results are not only relevant for seasonally saturated wetlands in this study, but they likely extend to floodplain wetlands as well (Scott et al. 2019).

The role of global wetlands as a future $\mathrm{C}$ sink or source is uncertain, as climate and land use change alter wetland area and biogeochemical processing (e.g., Dahl 2011; Kolka et al. 2018; Moomaw et al. 2018). While the wetlands in this study are relatively small in area, up to one-fifth of wetland area in this region experiences seasonally dynamic hydrology (MD iMAP 2016), and seasonally saturated wetlands are globally ubiquitous (Calhoun et al. 2017). Therefore, the seasonally saturated areas of many small wetlands are likely to have a large cumulative impact on SOC stocks on the landscape scale. Additionally, small wetlands are also disproportionately subject to loss from human activity (e.g., Van Meter and Basu 2015), causing a decline in wetland perimeter-to-area ratios and altering SOC storage. While wetland conservation and restoration tend to focus on restoring hydrology of large wetlands, our results indicate that small, seasonally saturated wetlands have a capacity for SOC storage and stability that must not be overlooked in conservation efforts. Our research emphasizes hydrologically dynamic soils of seasonally saturated wetlands as a critical but understudied component of landscape-scale wetland SOC storage and highlights the role of physicochemical mechanisms of SOC stabilization in soils across the wetlandupland continuum.

\section{Declarations}

\section{Funding}

This work was supported by a Graduate Research Assistantship from the National Socio-Environmental Synthesis Center (SESYNC; NSF Award DBI 1052875) in Annapolis, MD.

\section{Conflicts of interest}

The authors have no conflicts of interest to declare that are relevant to the content of this article.

\section{Availability of Data and Material}

Water level data can be found at www.doi.org/10.5281/zenodo.3879223. All soil sample data is available in the Supplementary Information (SI).

\section{Code availability}

Code used for hydrologic analysis can be found at www.doi.org/10.5281/zenodo.3879223. 


\section{References}

Anthony TL, Silver WL (2020) Mineralogical associations with soil carbon in managed wetland soils. Global Change Biology 26:6555-6567. https://doi.org/10.1111/gcb.15309

Arachchige PSP, Hettiarachchi GM, Rice CW, et al (2018) Sub-micron level investigation reveals the inaccessibility of stabilized carbon in soil microaggregates. Scientific Reports 8:

https://doi.org/10.1038/s41598-018-34981-9

Barr DJ, Levy R, Scheepers C, Tily HJ (2013) Random effects structure for confirmatory hypothesis testing: Keep it maximal. Journal of Memory and Language 68:255-278.

https://doi.org/10.1016/j.jml.2012.11.001

Bates D, Mächler M, Bolker B, Walker S (2015) Fitting Linear Mixed-Effects Models Using Ime4. Journal of Statistical Software 67:1-48. https://doi.org/10.18637/jss.v067.i01

Beare MH, Bruce RR (1993) a Comparison of Methods for Measuring Water-Stable Aggregates Implications for Determining Environmental-Effects on Soil Structure. Geoderma 56:87-104. https://doi.org/10.1016/0016-7061(93)90102-q

Blankinship JC, Fonte SJ, Six J, Schimel JP (2016) Plant versus microbial controls on soil aggregate stability in a seasonally dry ecosystem. Geoderma 272:39-50.

https://doi.org/10.1016/j.geoderma.2016.03.008

Bridgham SD, Megonigal JP, Keller JK, et al (2006) The carbon balance of North American wetlands. Wetlands 26:889-916. https://doi.org/10.1672/0277-5212(2006)26[889:TCBONA]2.0.C0;2

Brooks RT (2005) A review of basin morphology and pool hydrology of isolated ponded wetlands: implications for seasonal forest pools of the northeastern United States. Wetlands Ecology and Management 13:335-348. https://doi.org/10.1007/s11273-004-7526-5

Calhoun AJK, Mushet DM, Bell KP, et al (2017) Temporary wetlands: challenges and solutions to conserving a 'disappearing' ecosystem. Biological Conservation 211:3-11.

https://doi.org/10.1016/j.biocon.2016.11.024

Capps KA, Rancatti R, Tomczyk N, et al (2014) Biogeochemical Hotspots in Forested Landscapes: The Role of Vernal Pools in Denitrification and Organic Matter Processing. Ecosystems 17:1455-1468. https://doi.org/10.1007/s10021-014-9807-z

Castenson KL, Rabenhorst MC (2006) Indicator of Reduction in Soil (IRIS). Soil Science Society of America Journal 70:1222. https://doi.org/10.2136/sssaj2005.0130

Chanlabut U, Gomontean B, Srifa A (2020) Soil Organic Carbon Stocks across Hydrologic Schemes in Freshwater Wetlands of the Chi River Basin, Northeast Thailand. Wetlands 40:377-389. 
Chen C, Kukkadapu RK, Lazareva O, Sparks DL (2017) Solid-Phase Fe Speciation along the Vertical Redox Gradients in Floodplains using XAS and Mössbauer Spectroscopies. Environ Sci Technol 51:7903-7912. https://doi.org/10.1021/acs.est.7b00700

Cohen MJ, Creed IF, Alexander L, et al (2016) Do geographically isolated wetlands influence landscape functions? Proceedings of the National Academy of Sciences 113:1978-1986.

https://doi.org/10.1073/pnas.1512650113

Cosentino D, Chenu C, Le Bissonnais Y (2006) Aggregate stability and microbial community dynamics under drying-wetting cycles in a silt loam soil. Soil Biology and Biochemistry 38:2053-2062. https://doi.org/10.1016/j.soilbio.2005.12.022

Coward EK, Ohno T, Plante AF (2018) Adsorption and Molecular Fractionation of Dissolved Organic Matter on Iron-Bearing Mineral Matrices of Varying Crystallinity. Environmental Science \& Technology 52:1036-1044. https://doi.org/10.1021/acs.est.7b04953

Creed IF, Miller J, Aldred D, et al (2013) Hydrologic profiling for greenhouse gas effluxes from natural grasslands in the prairie pothole region of Canada. Journal of Geophysical Research: Biogeosciences 118:680-697. https://doi.org/10.1002/jgrg.20050

Cui H, Ou Y, Wang L, et al (2019) Distribution and release of phosphorus fractions associated with soil aggregate structure in restored wetlands. Chemosphere 223:319-329.

https://doi.org/10.1016/j.chemosphere.2019.02.046

Dahl TE (2011) Status and Trends of Wetlands in the Conterminous United States 2004 to 2009. U.S. Department of the Interior; Fish and Wildlife Service, Washington, D.C.

Darke AK, Walbridge MR (1994) Estimating non-crystalline and crystalline aluminum and iron by selective dissolution in a riparian forest soil. Communications in Soil Science and Plant Analysis 25:2089-2101. https://doi.org/10.1080/00103629409369174

Daugherty EE, McKee GA, Bergstrom R, et al (2019) Hydrogeomorphic controls on soil carbon composition in two classes of subalpine wetlands. Biogeochemistry 145:161-175.

https://doi.org/10.1007/s10533-019-00597-y

Denef K, Six J, Bossuyt H, et al (2001) Influence of dry-wet cycles on the interrelationship between aggregate, particulate organic matter, and microbial community dynamics. Soil Biology and Biochemistry 33:1599-1611. https://doi.org/10.1016/S0038-0717(01)00076-1

Denef K, Six J, Merckx R, Paustian K (2002) Short-term effects of biological and physical forces on aggregate formation in soils with different clay mineralogy. Plant and Soil 246:185-200.

https://doi.org/10.1023/A:1020668013524

Page 18/31 
Elliott ET, Palm CA, Reuss DE, Monz CA (1991) Organic matter contained in soil aggregates from a tropical chronosequence: correction for sand and light fraction. Agriculture, Ecosystems \& Environment 34:443-451. https://doi.org/10.1016/0167-8809(91)90127-J

Evenson GR, Jones CN, McLaughlin DL, et al (2018) A watershed-scale model for depressional wetlandrich landscapes. Journal of Hydrology X 1:100002. https://doi.org/10.1016/j.hydroa.2018.10.002

Fennessy MS, Wardrop DH, Moon JB, et al (2018) Soil carbon sequestration in freshwater wetlands varies across a gradient of ecological condition and by ecoregion. Ecological Engineering 114:129-136. https://doi.org/10.1016/j.ecoleng.2017.09.013

Fenstermacher D (2012) Carbon storage and potential carbon sequestration in depressional wetlands of the Mid-Atlantic region. University of Maryland

Fiedler S, Sommer M (2004) Water and Redox Conditions in Wetland Soils-Their Influence on Pedogenic Oxides and Morphology. Soil Science Society of America Journal 68:326-335.

https://doi.org/10.2136/sssaj2004.3260

Fissore C, Giardina CP, Kolka RK, Trettin CC (2009) Soil organic carbon quality in forested mineral wetlands at different mean annual temperature. Soil Biology and Biochemistry 41:458-466. https://doi.org/10.1016/j.soilbio.2008.11.004

Gee, GW, Bauder, JW (1986) Particle-size analysis. In: Klute, A (ed) Methods of soil analysis. Part 1. Physical and mineralogical methods. Soil Science Society of America, Madison, WI, pp 383-411

Gollany HT, Schumacher TE, Evenson PD, et al (1991) Aggregate Stability of an Eroded and Desurfaced Typic Argiustoll. Soil Science Society of America Journal 55:811. https://doi.org/10.2136/sssaj1991.03615995005500030030x

Griscom BW, Adams J, Ellis PW, et al (2017) Natural climate solutions. Proceedings of the National Academy of Sciences 114:11645-11650. https://doi.org/10.1073/pnas.1710465114

Hall SJ, Berhe AA, Thompson A (2018) Order from disorder: do soil organic matter composition and turnover co-vary with iron phase crystallinity? Biogeochemistry 140:93-110.

https://doi.org/10.1007/s10533-018-0476-4

Hefting M, Clément JC, Dowrick D, et al (2004) Water table elevation controls on soil nitrogen cycling in riparian wetlands along a European climatic gradient. Biogeochemistry 67:113-134.

https://doi.org/10.1023/B:BIOG.0000015320.69868.33

Herndon E, AlBashaireh A, Singer D, et al (2017) Influence of iron redox cycling on organo-mineral associations in Arctic tundra soil. Geochimica et Cosmochimica Acta 207:210-231.

https://doi.org/10.1016/j.gca.2017.02.034 
Hobson WA, Dahlgren RA (1998) Soil Forming Processes in Vernal Pools of Northern California, Chico Area. California Native Plant Society, Sacramento, CA

Hosen JD, Armstrong AW, Palmer MA (2018) Dissolved organic matter variations in coastal plain wetland watersheds: The integrated role of hydrological connectivity, land use, and seasonality. Hydrological Processes 32:1664-1681. https://doi.org/10.1002/hyp.11519

Hossler K, Bouchard V (2010) Soil development and establishment of carbon-based properties in created freshwater marshes. Ecological Applications 20:539-553. https://doi.org/10.1890/08-1330.1

Hurtt G, Zhao M, Sahajpal R, et al (2019) Beyond MRV: High-resolution forest carbon modeling for climate mitigation planning over Maryland, USA. Environmental Research Letters. https://doi.org/10.1088/17489326/ab0bbe

Jastrow JD (1996) Soil aggregate formation and the accrual of particulate and mineral-associated organic matter. Soil Biology and Biochemistry 28:665-676. https://doi.org/10.1016/00380717(95)00159-X

Kaiser, Guggenberger G (2007) Sorptive stabilization of organic matter by microporous goethite: sorption into small pores vs. surface complexation. European Journal of Soil Science 58:45-59. https://doi.org/10.1111/j.1365-2389.2006.00799.x

Kaiser K, Guggenberger G (2000) The role of DOM sorption to mineral surfaces in the preservation of organic matter in soils. Organic Geochemistry 31:711-725. https://doi.org/10.1016/S01466380(00)00046-2

Kaiser M, Kleber M, Berhe AA (2015) How air-drying and rewetting modify soil organic matter characteristics: An assessment to improve data interpretation and inference. Soil Biology and Biochemistry 80:324-340. https://doi.org/10.1016/j.soilbio.2014.10.018

Keiluweit M, Gee K, Denney A, Fendorf S (2018) Anoxic microsites in upland soils dominantly controlled by clay content. Soil Biology and Biochemistry 118:42-50. https://doi.org/10.1016/j.soilbio.2017.12.002

Kleber M, Mikutta R, Torn MS, Jahn R (2005) Poorly crystalline mineral phases protect organic matter in acid subsoil horizons. European Journal of Soil Science 56:717-725. https://doi.org/10.1111/j.13652389.2005.00706.x

Kögel-Knabner I, Guggenberger G, Kleber M, et al (2008) Organo-mineral associations in temperate soils: Integrating biology, mineralogy, and organic matter chemistry. Journal of Plant Nutrition and Soil Science 171:61-82. https://doi.org/10.1002/jpln.200700048

Kolka RK, Trettin C, Tang W, et al (2018) Chapter 13: Terrestrial Wetlands. In Second State of the Carbon Cycle Report (SOCCR2): A Sustained Assessment Report. U.S. Global Change Research Program, Washington, DC, USA 
Kramer MG, Chadwick OA (2018) Climate-driven thresholds in reactive mineral retention of soil carbon at the global scale. Nature Climate Change 8:1104-1108. https://doi.org/10.1038/s41558-018-0341-4

Krause S, Lewandowski J, Grimm NB, et al (2017) Ecohydrological interfaces as hot spots of ecosystem processes. Water Resources Research 53:6359-6376. https://doi.org/10.1002/2016WR019516

Kuznetsova A, Brockhoff PB, Christensen RHB (2017) ImerTest Package: Tests in Linear Mixed Effects Models. Journal of Statistical Software 82:1-26. https://doi.org/10.18637/jss.v082.i13

LaCroix RE, Tfaily MM, McCreight M, et al (2019) Shifting mineral and redox controls on carbon cycling in seasonally flooded mineral soils. Biogeosciences 16:2573-2589. https://doi.org/10.5194/bg-16-25732019

Lang M, McCarty G, Oesterling R, Yeo I-Y (2013) Topographic Metrics for Improved Mapping of Forested Wetlands. Wetlands 33:141-155. https://doi.org/10.1007/s13157-012-0359-8

Lang MW, McCarty GW (2009) Lidar intensity for improved detection of inundation below the forest canopy. Wetlands 29:1166-1178. https://doi.org/10.1672/08-197.1

Lee S, McCarty GW, Moglen GE, et al (2020) Seasonal drivers of geographically isolated wetland hydrology in a low-gradient, Coastal Plain landscape. Journal of Hydrology 583:124608. https://doi.org/10.1016/j.jhydrol.2020.124608

Lehmann J, Kleber M (2015) The contentious nature of soil organic matter. Nature 528:60-68. https://doi.org/10.1038/nature16069

Ligi T, Truu M, Truu J, et al (2014) Effects of soil chemical characteristics and water regime on denitrification genes (nirS, nirK, and nosZ) abundances in a created riverine wetland complex. Ecological Engineering 72:47-55. https://doi.org/10.1016/j.ecoleng.2013.07.015

Lopez-Sangil L, Rovira P (2013) Sequential chemical extractions of the mineral-associated soil organic matter: An integrated approach for the fractionation of organo-mineral complexes. Soil Biology and Biochemistry 62:57-67. https://doi.org/10.1016/j.soilbio.2013.03.004

Maietta CE, Bernstein ZA, Gaimaro JR, et al (2019) Aggregation but Not Organo-Metal Complexes Contributed to C Storage in Tidal Freshwater Wetland Soils. Soil Science Society of America Journal 83:252. https://doi.org/10.2136/sssaj2018.05.0199

Miao G, Noormets A, Domec J-C, et al (2017) Hydrology and microtopography control carbon dynamics in wetlands: Implications in partitioning ecosystem respiration in a coastal plain forested wetland. Agricultural and Forest Meteorology 247:343-355. https://doi.org/10.1016/j.agrformet.2017.08.022

Mikutta R, Kleber M, Torn MS, Jahn R (2006) Stabilization of Soil Organic Matter: Association with Minerals or Chemical Recalcitrance? Biogeochemistry 77:25-56. https://doi.org/10.1007/s10533-005- 
Mikutta R, Lorenz D, Guggenberger G, et al (2014) Properties and reactivity of Fe-organic matter associations formed by coprecipitation versus adsorption: Clues from arsenate batch adsorption. Geochimica et Cosmochimica Acta 144:258-276. https://doi.org/10.1016/j.gca.2014.08.026

Mitsch WJ, Bernal B, Nahlik AM, et al (2013) Wetlands, carbon, and climate change. Landscape Ecology 28:583-597. https://doi.org/10.1007/s10980-012-9758-8

Mitsch WJ, Gosselink JG (2015) Wetlands, 5. ed. John Wiley and Sons, Inc, Hoboken, NJ

Moni C, Rumpel C, Virto I, et al (2010) Relative importance of sorption versus aggregation for organic matter storage in subsoil horizons of two contrasting soils. European Journal of Soil Science 61:958969. https://doi.org/10.1111/j.1365-2389.2010.01307.x

Moomaw WR, Chmura GL, Davies GT, et al (2018) Wetlands In a Changing Climate: Science, Policy and Management. Wetlands 38:183-205. https://doi.org/10.1007/s13157-018-1023-8

Oades JM (1988) The retention of organic matter in soils. Biogeochemistry 5:35-70. https://doi.org/10.1007/BF02180317

Park E-J, Sul WJ, Smucker AJM (2007) Glucose additions to aggregates subjected to drying/wetting cycles promote carbon sequestration and aggregate stability. Soil Biology and Biochemistry 39:27582768. https://doi.org/10.1016/j.soilbio.2007.06.007

Pearse AL, Barton JL, Lester RE, et al (2018) Soil organic carbon variability in Australian temperate freshwater wetlands: Temperate wetland soil organic carbon variability. Limnology and Oceanography 63:S254-S266. https://doi.org/10.1002/Ino.10735

Phillips PJ, Shedlock RJ (1993) Hydrology and chemistry of groundwater and seasonal ponds in the Atlantic Coastal Plain in Delaware, USA. Journal of Hydrology 141:157-178.

https://doi.org/10.1016/0022-1694(93)90048-E

Poeplau C, Vos C, Don A (2017) Soil organic carbon stocks are systematically overestimated by misuse of the parameters bulk density and rock fragment content. SOIL 3:61-66. https://doi.org/10.5194/soil-361-2017

Puget P, Chenu C, Balesdent J (2000) Dynamics of soil organic matter associated with particle-size fractions of water-stable aggregates. European Journal of Soil Science 51:595-605. https://doi.org/10.1046/j.1365-2389.2000.00353.x

R Development Core Team R: A language and environment for statistical computing. https://www.rproject.org/ 
Rabenhorst MC (2018) A System for Making and Deploying Oxide-Coated Plastic Films for Environmental Assessment of Soils. Soil Science Society of America Journal 82:1301.

https://doi.org/10.2136/sssaj2018.05.0178

Rasmussen C, Heckman K, Wieder WR, et al (2018) Beyond clay: towards an improved set of variables for predicting soil organic matter content. Biogeochemistry 137:297-306. https://doi.org/10.1007/s10533018-0424-3

Riedel T, Zak D, Biester H, Dittmar T (2013) Iron traps terrestrially derived dissolved organic matter at redox interfaces. Proceedings of the National Academy of Sciences 110:10101-10105.

https://doi.org/10.1073/pnas.1221487110

Rosenberry DO, Winter TC (1997) Dynamics of water-table fluctuations in an upland between two prairiepothole wetlands in North Dakota. Journal of Hydrology 191:266-289. https://doi.org/10.1016/S00221694(96)03050-8

Schmidt MWI, Torn MS, Abiven S, et al (2011) Persistence of soil organic matter as an ecosystem property. Nature 478:49-56. https://doi.org/10.1038/nature10386

Scott DT, Gomez-Velez JD, Jones CN, Harvey JW (2019) Floodplain inundation spectrum across the United States. Nature Communications 10:. https://doi.org/10.1038/s41467-019-13184-4

Six J, Bossuyt H, Degryze S, Denef K (2004) A history of research on the link between (micro)aggregates, soil biota, and soil organic matter dynamics. Soil and Tillage Research 79:7-31.

https://doi.org/10.1016/j.still.2004.03.008

Six J, Callewaert P, Lenders S, et al (2002) Measuring and Understanding Carbon Storage in Afforested Soils by Physical Fractionation. Soil Science Society of America Journal 66:1981. https://doi.org/10.2136/sssaj2002.1981

Six J, Elliott ET, Paustian K (2000) Soil macroaggregate turnover and microaggregate formation: a mechanism for $C$ sequestration under no-tillage agriculture. Soil Biology and Biochemistry 32:20992103. https://doi.org/10.1016/S0038-0717(00)00179-6

Sodano M, Lerda C, Nisticò R, et al (2017) Dissolved organic carbon retention by coprecipitation during the oxidation of ferrous iron. Geoderma 307:19-29. https://doi.org/10.1016/j.geoderma.2017.07.022

State of Maryland (2016) Maryland Wetlands - Wetlands (National Wetlands Inventory). In: MD iMAP. opendata.maryland.gov

Stolt MH, Rabenhorst MC (1987) Carolina Bays on the Eastern Shore of Maryland: I. Soil Characterization and Classification1. Soil Science Society of America Journal 51:394.

https://doi.org/10.2136/sssaj1987.03615995005100020025x 
Sugimura Y, Suzuki Y (1988) A high-temperature catalytic oxidation method for the determination of nonvolatile dissolved organic carbon in seawater by direct injection of a liquid sample. Marine Chemistry 24:105-131

Tangen BA, Bansal S (2020) Soil organic carbon stocks and sequestration rates of inland, freshwater wetlands: Sources of variability and uncertainty. Science of The Total Environment 749:141444. https://doi.org/10.1016/j.scitotenv.2020.141444

Torn MS, Trumbore SE, Chadwick OA, et al (1997) Mineral control of soil organic carbon storage and turnover. Nature 389:170-173. https://doi.org/10.1038/38260

Totsche KU, Amelung W, Gerzabek MH, et al (2018) Microaggregates in soils. Journal of Plant Nutrition and Soil Science 181:104-136. https://doi.org/10.1002/jpln.201600451

Trettin CC, Song B, Jurgensen MF, Li C (2001) Existing Soil Carbon Models Do Not Apply to Forested Wetlands. Gen Tech Rep SRS-46 Asheville, NC: US Department of Agriculture, Forest Service, Southern Research Station 10 p 046:

Van Meter KJ, Basu NB (2015) Signatures of human impact: size distributions and spatial organization of wetlands in the Prairie Pothole landscape. Ecological Applications 25:451-465. https://doi.org/10.1890/14-0662.1

von Lützow M, Kogel-Knabner I, Ekschmitt K, et al (2006) Stabilization of organic matter in temperate soils: mechanisms and their relevance under different soil conditions - a review. European Journal of Soil Science 57:426-445. https://doi.org/10.1111/j.1365-2389.2006.00809.x

von Lützow M, Kögel-Knabner I, Ekschmitt K, et al (2007) SOM fractionation methods: Relevance to functional pools and to stabilization mechanisms. Soil Biology and Biochemistry 39:2183-2207. https://doi.org/10.1016/j.soilbio.2007.03.007

Wagai R, Mayer LM (2007) Sorptive stabilization of organic matter in soils by hydrous iron oxides. Geochimica et Cosmochimica Acta 71:25-35. https://doi.org/10.1016/j.gca.2006.08.047

Wagai R, Mayer LM, Kitayama K, Shirato Y (2013) Association of organic matter with iron and aluminum across a range of soils determined via selective dissolution techniques coupled with dissolved nitrogen analysis. Biogeochemistry 112:95-109. https://doi.org/10.1007/s10533-011-9652-5

Wagner S, Cattle SR, Scholten T (2007) Soil-aggregate formation as influenced by clay content and organic-matter amendment. Journal of Plant Nutrition and Soil Science 170:173-180. https://doi.org/10.1002/jpln.200521732

Walter K, Don A, Tiemeyer B, Freibauer A (2016) Determining Soil Bulk Density for Carbon Stock Calculations: A Systematic Method Comparison. Soil Science Society of America Journal 80:579. https://doi.org/10.2136/sssaj2015.11.0407 
Wang H, River M, Richardson CJ (2019) Does an 'iron gate' carbon preservation mechanism exist in organic-rich wetlands? Soil Biology and Biochemistry 135:48-50.

https://doi.org/10.1016/j.soilbio.2019.04.011

Wang Y, Wang H, He J-S, Feng X (2017) Iron-mediated soil carbon response to water-table decline in an alpine wetland. Nature Communications 8:. https://doi.org/10.1038/ncomms15972

Webster KL, Creed IF, Beall FD, Bourbonnière RA (2011) A topographic template for estimating soil carbon pools in forested catchments. Geoderma 160:457-467. https://doi.org/10.1016/j.geoderma.2010.10.016

Webster KL, Creed IF, Bourbonnière RA, Beall FD (2008) Controls on the heterogeneity of soil respiration in a tolerant hardwood forest. Journal of Geophysical Research 113:.

https://doi.org/10.1029/2008JG000706

Weil R, Brady N (2017) The Nature and Properties of Soils, 15th edn. Pearson Press

Wickham H (2017) tidyverse: Easily Install and Load the Tidyverse. R package version 1.2.1.

https://www.tidyverse.org/

Wilke C (2019) cowplot: Streamlined Plot Theme and Plot Annotations for "ggplot2". R package version 0.9.4). https://CRAN.R-project.org/package=cowplot

Zedler PH (2003) Vernal pools and the concept of "isolated wetlands." Wetlands 23:597-607. https://doi.org/10.1672/0277-5212(2003)023[0597:VPATCO]2.0.CO;2

Zuur A, leno EN, Walker N, et al (2009) Mixed Effects Models and Extensions in Ecology with R. Springer Science and Business Media

National Cooperative Soil Characterization Database. Natural Resources Conservation Service (2017) Climate Science Special Report: Fourth National Climate Assessment, Volume I. U.S. Global Change Research Program, Washington, DC, USA

\section{Table}

Table 1 Description of soil parameters, units, method of measurement or calculation, and their description 


\begin{tabular}{|c|c|c|c|c|}
\hline Property & Variable & Abbreviation & $\begin{array}{ll}\text { it } & \text { Source or } \\
& \text { Equation }\end{array}$ & Description \\
\hline \multirow[t]{3}{*}{$\begin{array}{l}\text { Bulk Soil } \\
\text { C }\end{array}$} & $\begin{array}{l}\text { Bulk soil C } \\
\text { concentratior }\end{array}$ & $\mathrm{C}_{\text {bulk }}$ & $\begin{array}{l}\% ; \mathrm{g} \mathrm{C} \cdot \mathrm{g}^{-\mathrm{CHN}} \text { Analyzer } \\
{ }^{1} \text { soil }\end{array}$ & Concentration of $\mathrm{C}$ in the bulk soil sample. \\
\hline & Bulk soil C:N & $\mathrm{C}: \mathrm{N}_{\text {bulk }}$ & $\begin{array}{l}\text { ratio; g C CHN Analyzer } \\
\cdot \mathrm{g}^{-1} \mathrm{~N}\end{array}$ & Ratio of $\mathrm{C}: \mathrm{N}$ in bulk soil. \\
\hline & Soil C stock & C Stock & $\begin{aligned} \mathrm{kg} \mathrm{C} \cdot \mathrm{m}^{-2} \mathrm{C}_{\text {bulk }}{ }^{*} \text { bulk } \\
\text { density*l }\end{aligned}$ & $\begin{array}{l}\text { Carbon stock in a given length increment, } \\
\text { calculated by multiplying the C } \\
\text { concentration in each depth increment by } \\
\text { the bulk density and sample length. }\end{array}$ \\
\hline \multirow[t]{5}{*}{$\begin{array}{l}\text { Aggregate } \\
\text { Size Class }\end{array}$} & $\begin{array}{l}\text { Aggregate } \\
\text { fraction mass }\end{array}$ & & g ${ }_{\text {aggregate }}$ mass $_{\text {aggregate }}$ & $\begin{array}{l}\text { Mass of aggregate size class after air } \\
\text { drying and removal of rocks ( }>1 \mathrm{~mm}) \text {. }\end{array}$ \\
\hline & $\begin{array}{l}\text { Aggregate } \\
C: N\end{array}$ & $\mathrm{C}: \mathrm{N}_{\text {aggregate }}$ & $\begin{array}{l}\text { ratio; g C CHN Analyzer } \\
\cdot \mathrm{g}^{-1} \mathrm{~N}\end{array}$ & $\begin{array}{l}\text { Ratio of C:N within an aggregate size } \\
\text { class. }\end{array}$ \\
\hline & $\begin{array}{l}\text { Aggregate } \mathrm{C} \\
\text { concentratior }\end{array}$ & $\mathrm{C}_{\text {aggregate }}$ & $\begin{array}{l}\text { mg } \mathrm{C} \cdot \mathrm{g}^{-1} \mathrm{CHN} \text { Analyzer; } \\
\text { soil }\end{array}$ & $\begin{array}{l}\text { Concentration of } \mathrm{C} \text { in each aggregate size } \\
\text { class per gram of bulk soil, excluding }\end{array}$ \\
\hline & & & mass $_{\text {total }}$ & /10CKS. \\
\hline & $\begin{array}{l}\text { Normalized } \\
\text { aggregate- } \\
\text { associated C }\end{array}$ & $\mathrm{C}_{\text {aggregate }} / \mathrm{C}_{\mathrm{bul}}$ & $\begin{array}{c}\mathrm{kmg} \mathrm{C} \cdot \mathrm{g}^{-1}\left(\mathrm{C}^{*} \mathrm{mass}_{\text {aggregate }}\right) / \\
\mathrm{C}\left(\mathrm{C}^{*} \text { mass }_{\text {aggregate }}\right) \\
\text { (Eq. 1) }\end{array}$ & $\begin{array}{l}\text { /Proportion of C associated with an } \\
\text { aggregate fraction, normalized to C of the } \\
\text { entire sample. Indicates the relative } \\
\text { proportion of C in each aggregate fraction, } \\
\text { normalized for differences in bulk soil C } \\
\text { across the transect. }\end{array}$ \\
\hline \multirow[t]{3}{*}{$\begin{array}{l}\text { Bulk Soil } \\
\text { Fe }\end{array}$} & $\begin{array}{l}\text { Poorly } \\
\text { crystalline } \mathrm{Fe}\end{array}$ & $\mathrm{Fe}_{\mathrm{AAO}}$ & $\begin{array}{l}\mathrm{mg} \mathrm{Fe} \cdot \mathrm{g}^{\text {-Atomic absorption }} \\
\text { spectrometer }\end{array}$ & $\begin{array}{l}\text { Concentration of poorly crystalline Fe } \\
\text { species, extracted by AAO. }\end{array}$ \\
\hline & Total Fe & $\mathrm{Fe}_{\mathrm{DCB}}$ & $\begin{array}{l}\operatorname{mg~Fe} \cdot \mathrm{g}_{\text {soil }}^{\text {-Atomic absorption }} \\
\text { spectrometer }\end{array}$ & $\begin{array}{l}\text { Concentration of total (crystalline and } \\
\text { poorly crystalline) Fe species, extracted by } \\
\text { DCB. }\end{array}$ \\
\hline & $\begin{array}{l}\text { Percent } \\
\text { poorly } \\
\text { crystalline } \mathrm{Fe}\end{array}$ & $\mathrm{Fe}_{\mathrm{AAO}} / \mathrm{Fe}_{\mathrm{DCB}}$ & $\mathrm{Fe}_{\mathrm{AAO}} / \mathrm{Fe}_{\mathrm{DCB}} * 100$ & $\begin{array}{l}\text { Percent of total Fe that is poorly } \\
\text { crystalline. }\end{array}$ \\
\hline \multirow[t]{4}{*}{$\begin{array}{l}\text { Fe-C } \\
\text { Association }\end{array}$} & 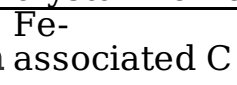 & $\mathrm{C}_{\text {Dit-HCl }}$ & $\begin{array}{l}\mathrm{mg} \mathrm{C} \cdot \mathrm{g}^{-1} \mathrm{TOC} \text { Analyzer } \\
\text { soil }\end{array}$ & $\begin{array}{l}\text { Concentration of C extracted with Dit-HCl, } \\
\text { an inorganic extraction for total Fe. }\end{array}$ \\
\hline & Extracted Fe & $\mathrm{Fe}_{\text {Dit-HCl }}$ & $\begin{array}{l}\text { mg Fe } \cdot \mathrm{g}^{\text {-Atomic absorption }} \\
{ }_{1}^{1} \text { soil }\end{array}$ & $\begin{array}{l}\text { Concentration of Fe extracted with Dit- } \\
\text { HCl. }\end{array}$ \\
\hline & $\begin{array}{l}\text { Normalized } \\
\text { Fe- } \\
\text { associated C }\end{array}$ & $\mathrm{C}_{\text {Dit-HCl}} / \mathrm{C}_{\text {bulk }}$ & 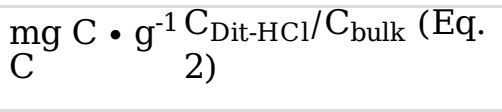 & $\begin{array}{l}\text { Proportion of } \mathrm{C} \text { associated with } \mathrm{Fe}_{\mathrm{Dit}-\mathrm{HCl}} \\
\text { normalized to bulk soil C. }\end{array}$ \\
\hline & $\begin{array}{l}\text { Extractant } \\
\mathrm{C}: \mathrm{Fe}\end{array}$ & $\begin{array}{l}\mathrm{C}_{\text {Dit-HCl}}: \mathrm{Fe}_{\text {Dit- }} \\
\mathrm{HCl}\end{array}$ & $\begin{array}{l}\text { ratio; g C } \mathrm{C}_{\text {Dit-HCl }} / \mathrm{Fe}_{\text {Dit-HCl }} \\
\text { - } \mathrm{g}^{-1} \mathrm{Fe}\end{array}$ & $\begin{array}{l}\text { Ratio of extracted } \mathrm{C} \text { to extracted Fe; } \\
\text { indicates the kind of association between } \\
\mathrm{C} \text { and Fe. }\end{array}$ \\
\hline
\end{tabular}

\section{Figures}



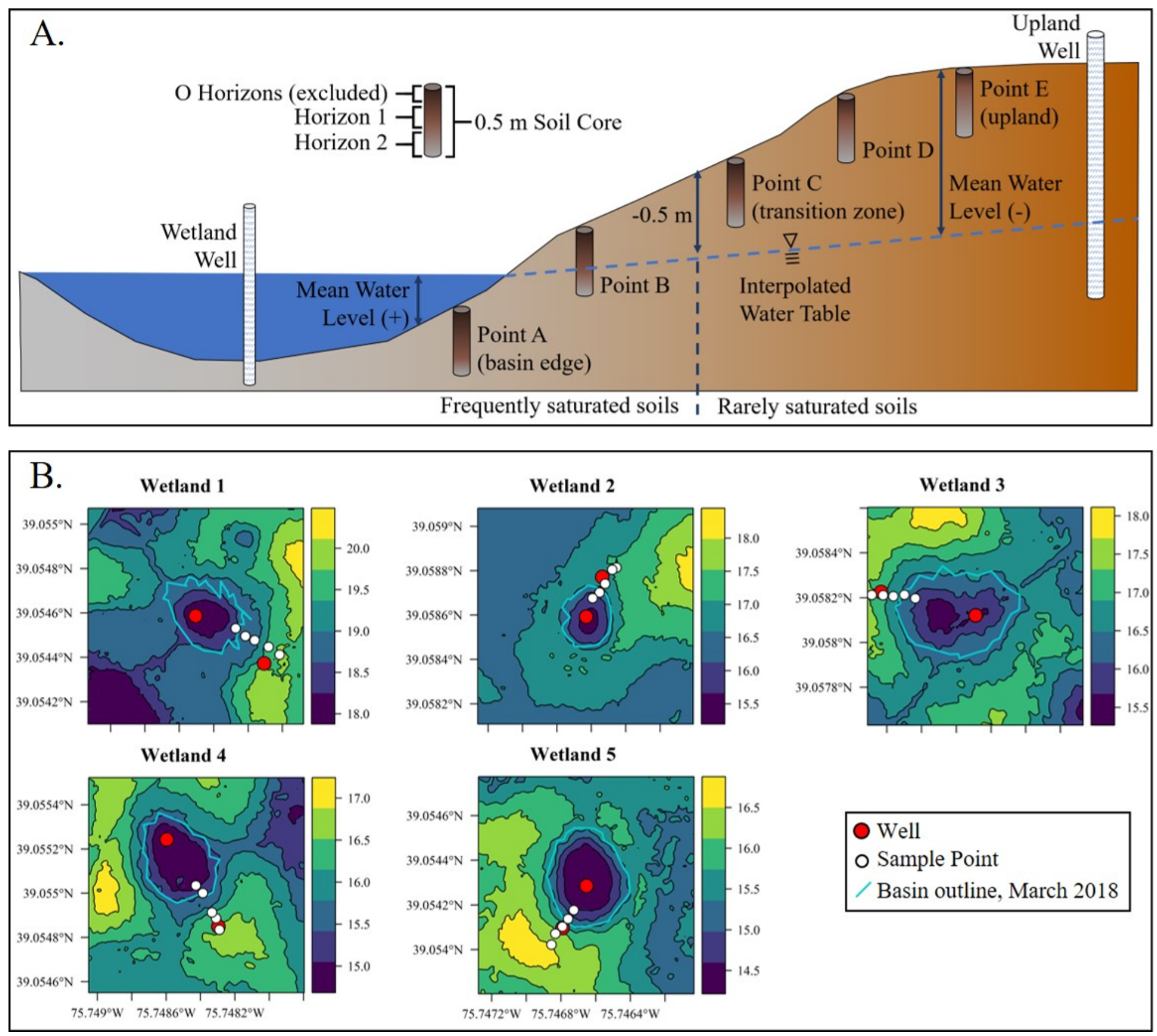

Figure 1

Cross-section schematic of theoretical sampling design (Panel A). Elevation gradient shown is exaggerated. Panel $B$ shows actual location of wells and transects in wetlands that vary in topographic relief. Basin outline is the minimum extent of ponded water for each wetland 

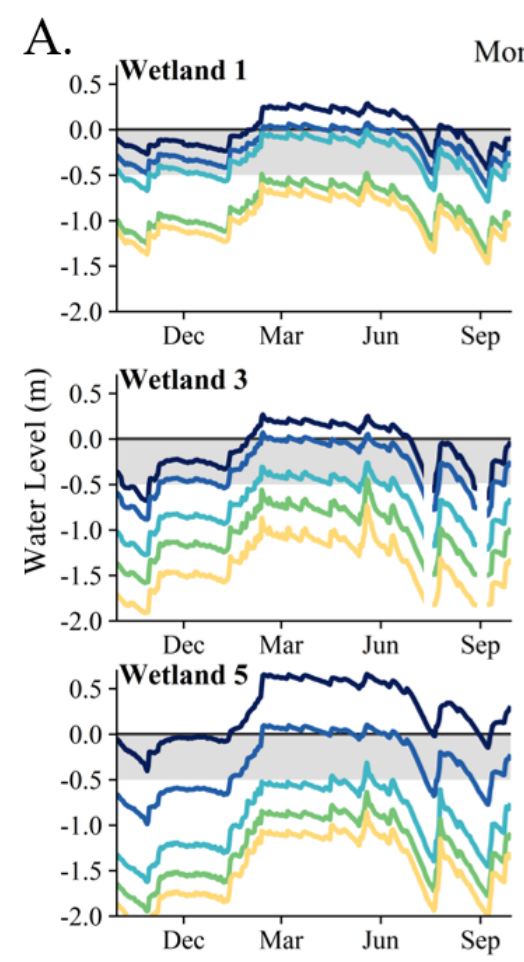

Month
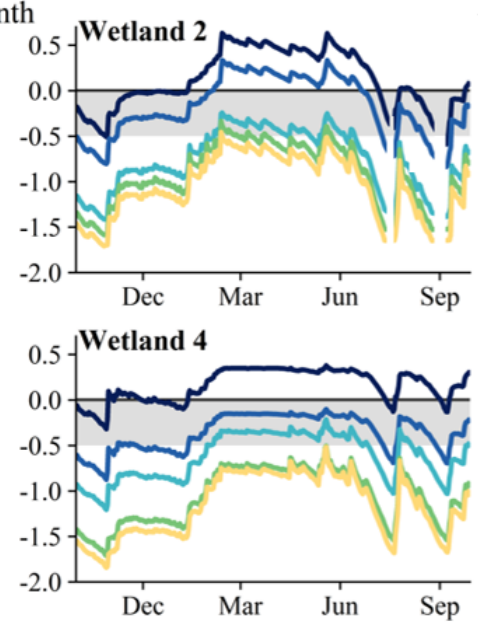

Figure Legend

Upper $0.5 \mathrm{~m}$ of soil

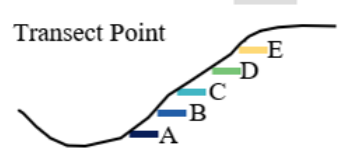

B.

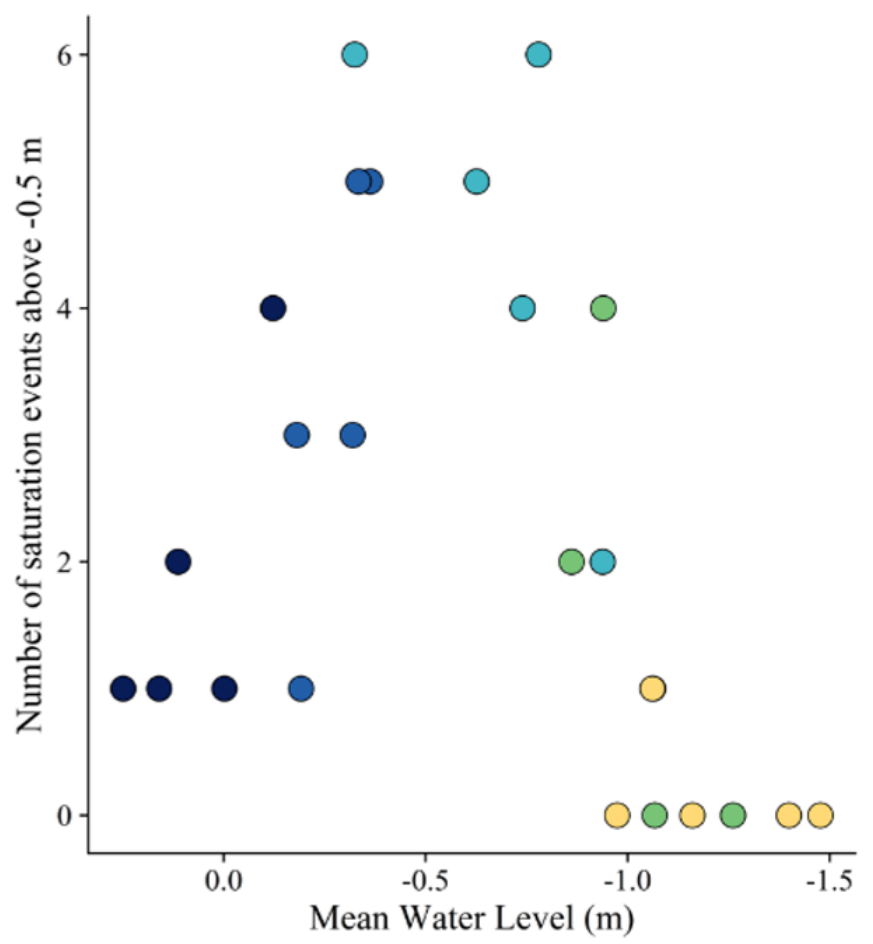

\section{Figure 2}

Daily water levels at each wetland show differing hydrologic conditions across categorical transect points (Panel A). The black line indicates the soil surface, and the shaded grey band indicates upper 0.5 $\mathrm{m}$ of soil profile. As an indicator of hydrologic variability in at each sample point, we show the number of times ("event") during the study year that the water table rose to within $0.5 \mathrm{~m}$ of the soil surface (i.e., mean water level above $-0.5 \mathrm{~m}$; Panel B) 
A. $\mathbf{C}_{\text {bulk }}$ concentrations

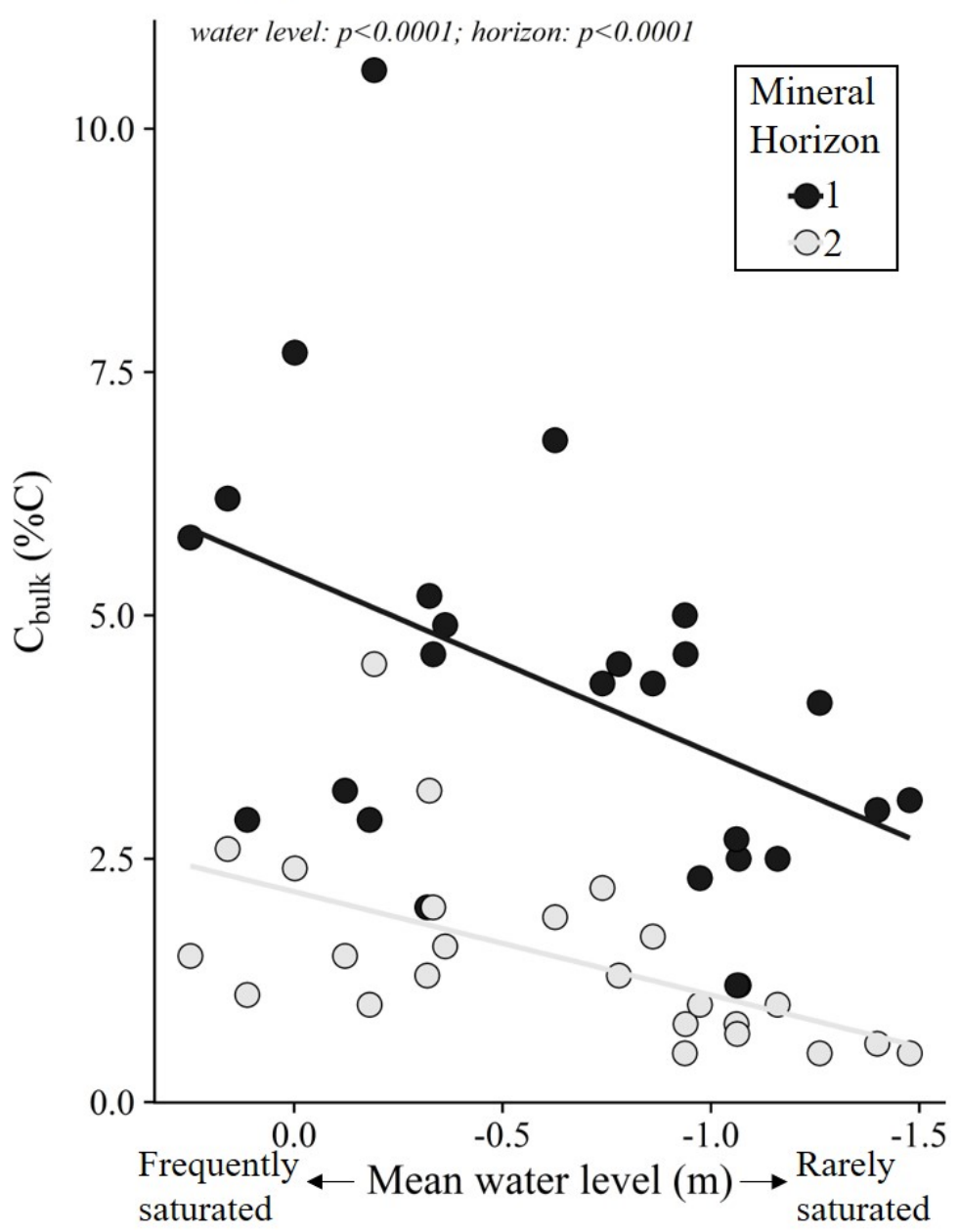

\section{B. C stocks 0-10 cm by water level}

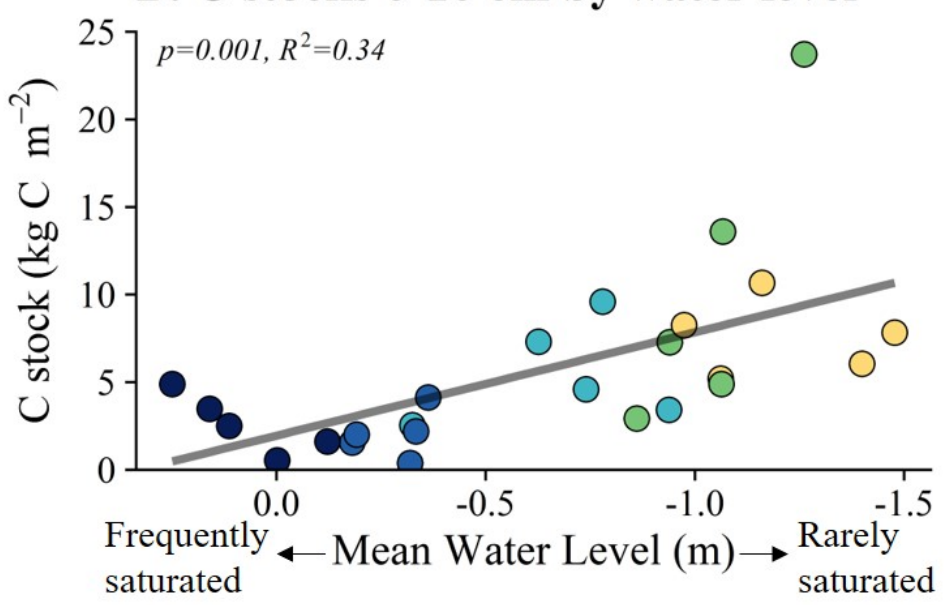

C. C stocks $10-50 \mathrm{~cm}$ by water level

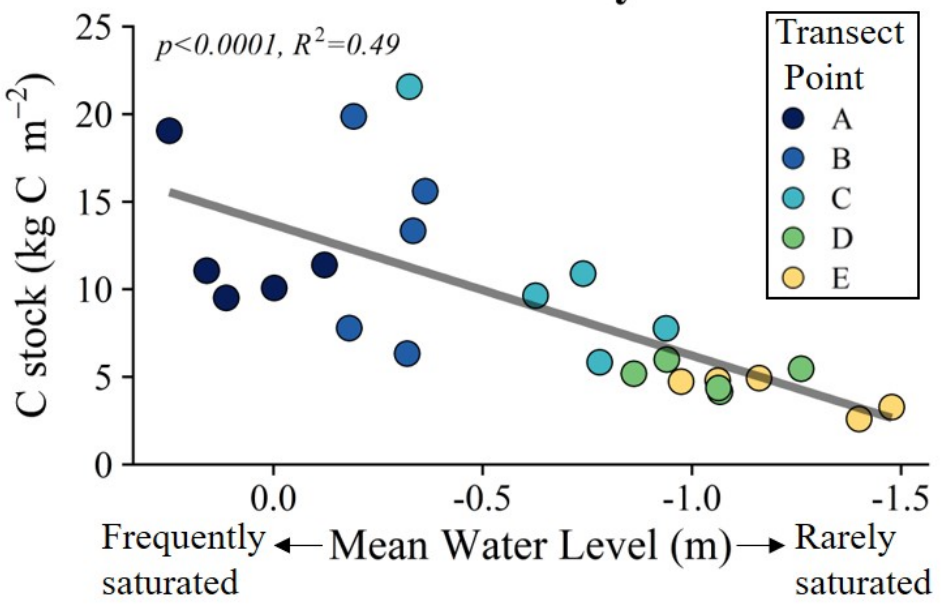

Figure 3

Soil C properties for all samples. Panel A shows bulk soil C (\%) by horizon vs. mean water level, with significant models from the reduced LME presented as solid lines $(P<0.05)$. Panels $B$ and $C$ depict SOC stocks ( $\mathrm{kg} \mathrm{C} \mathrm{m-2)} \mathrm{for} \mathrm{0-10} \mathrm{cm}$ and 10-50 cm depths, respectively, with significant models from the SLR presented as solid lines. Statistical results in Supplementary Tables 3-4 
A. Large Macro. $\mathbf{C}_{\text {aggregate }}$

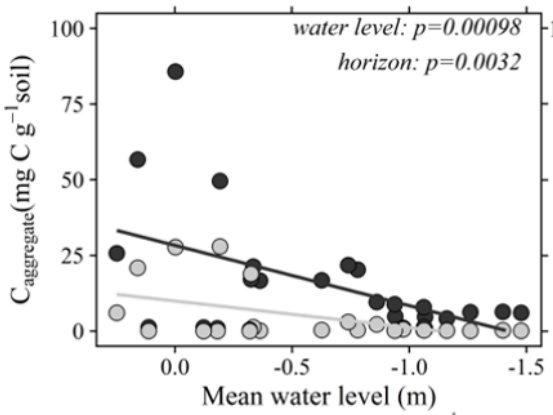

B. Small Macro. $C_{\text {aggregate }}$

C. Microagg. $\mathrm{C}_{\text {aggregate }}$

D. Silt/Clay $\mathbf{C}_{\text {aggregate }}$

E. Large Macro. $\mathbf{C}_{\text {aggregate }} / \mathbf{C}_{\text {bulk }}$
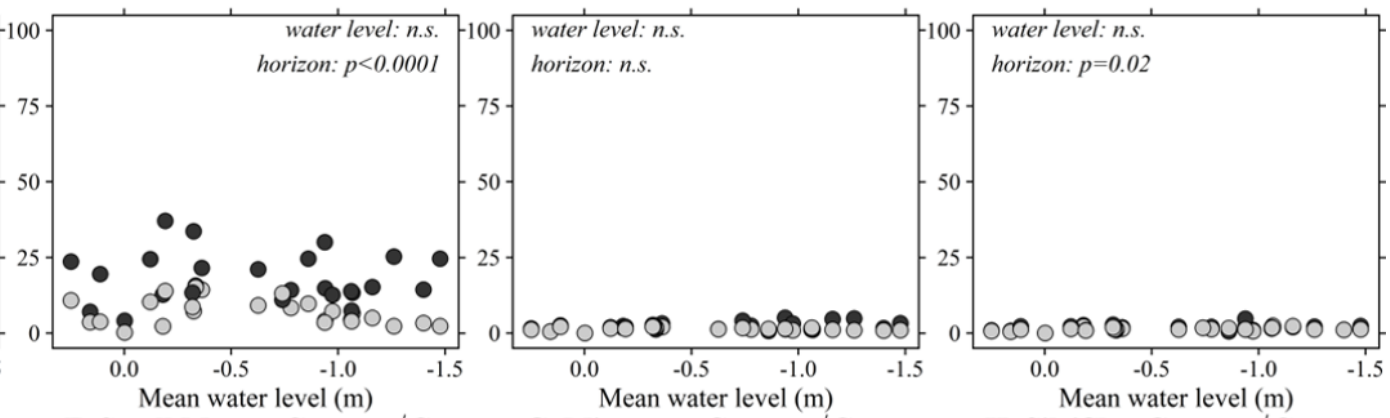

F. Small Macro. $C_{\text {aggregate }} / \mathbf{C}_{\text {bulk }}$

G. Microagg. $C_{\text {aggregate }} / \mathbf{C}_{\text {bulk }}$

H. Silt/Clay $\mathbf{C}_{\text {aggregate }} / \mathbf{C}_{\text {bulk }}$
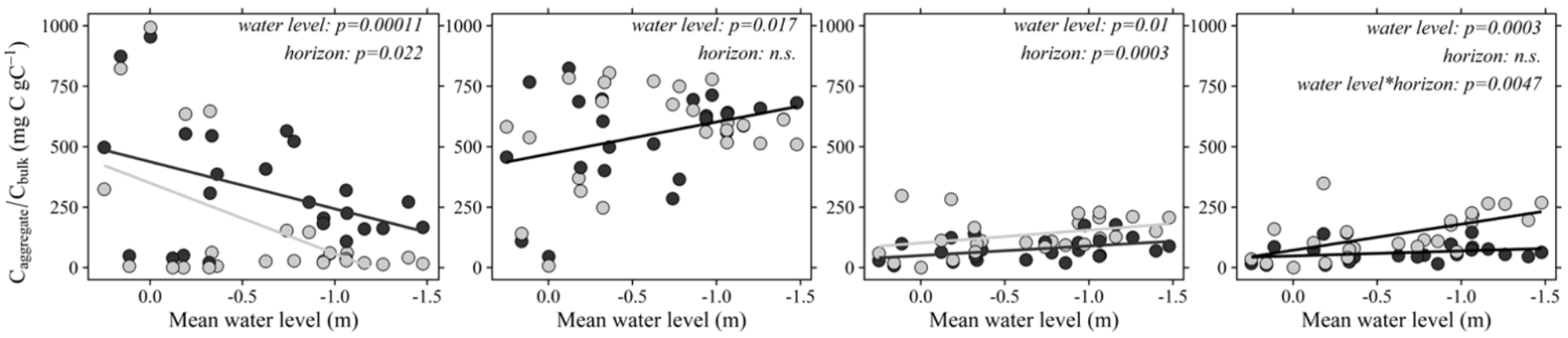

Figure 4

Aggregate C (Caggregate) and normalized Aggregate-Associated C (Caggregate/Cbulk) vs. mean water level (from frequently saturated soils to rarely saturated soils), by aggregate size class. Solid lines represent significant differences across mean water level in the LME models. Statistical results in Supplementary Information

A. Fe concentration $\left(\mathrm{Fe}_{\text {Dit-HCl}}\right)$ Horizon: $1 \bullet 20$

B. Fe-associated $\mathbf{C}$ concentration $\left(\mathrm{C}_{\mathrm{Dit}-\mathrm{HCl}}\right)$

C. Norm. Fe-associated C $\left(\mathrm{C}_{\text {Dit-HCl }} / \mathrm{C}_{\text {bulk }}\right)$
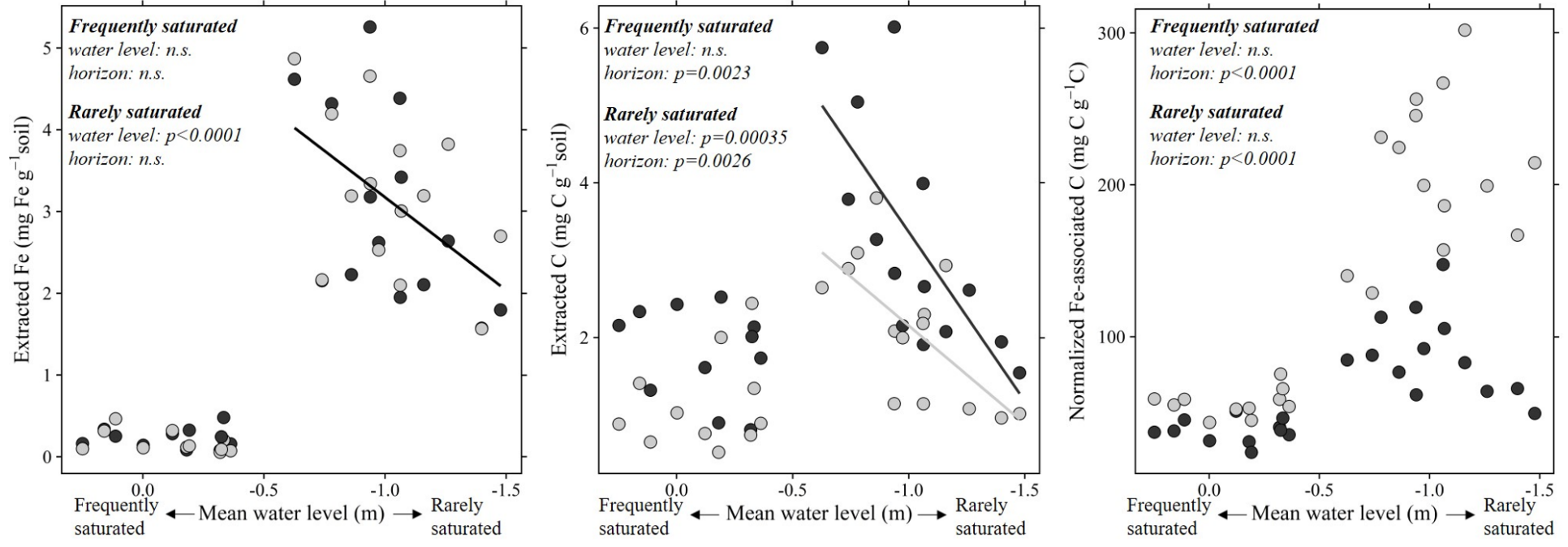

Figure 5

Results from Dit-HCl extractions. Panel A shows FeDit-HCl concentrations, Panel C shows Fe-associated $\mathrm{CDit}-\mathrm{HCl}$ concentrations, and Panel $\mathrm{C}$ shows the normalized CDit-HCl/Cbulk. Data were separated at a mean water level of $-0.5 \mathrm{~m}$ into frequently saturated soils and rarely saturated soils for analysis. Solid 
lines represent LME models where mean water level is significant. Only one line is shown for the LME model where differences between horizon are not significant. Statistical results in Supplementary Information

\section{Supplementary Files}

This is a list of supplementary files associated with this preprint. Click to download.

- SupplementaryInformationBGC.docx 